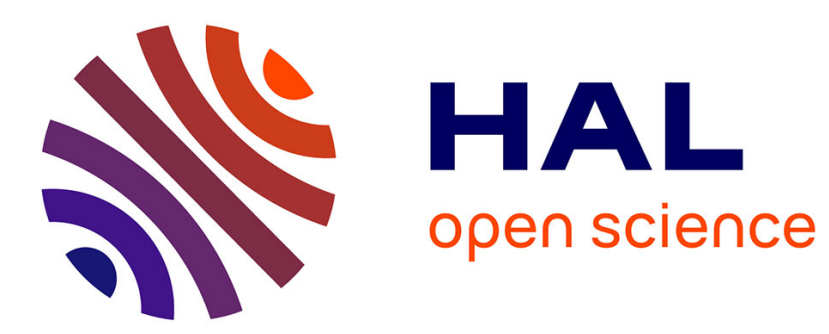

\title{
Sediment dynamics and morphological evolution in the Tagus Estuary inlet
}

André B Fortunato, P. Freire, B. Mengual, X. Bertin, C. Pinto, K. Martins, T. Guérin, A. Azevedo

\section{- To cite this version:}

André B Fortunato, P. Freire, B. Mengual, X. Bertin, C. Pinto, et al.. Sediment dynamics and morphological evolution in the Tagus Estuary inlet. Marine Geology, 2021, 440, pp.106590. 10.1016/j.margeo.2021.106590 . hal-03454586

HAL Id: hal-03454586

\section{https://hal-univ-rochelle.archives-ouvertes.fr/hal-03454586}

Submitted on 29 Nov 2021

HAL is a multi-disciplinary open access archive for the deposit and dissemination of scientific research documents, whether they are published or not. The documents may come from teaching and research institutions in France or abroad, or from public or private research centers.
L'archive ouverte pluridisciplinaire HAL, est destinée au dépôt et à la diffusion de documents scientifiques de niveau recherche, publiés ou non, émanant des établissements d'enseignement et de recherche français ou étrangers, des laboratoires publics ou privés. 


\title{
Sediment dynamics and morphological evolution in the Tagus Estuary inlet
}

\author{
A.B. Fortunato, ${ }^{1 *}$ P. Freire, ${ }^{1}$ B. Mengual,${ }^{2,3}$ X. Bertin, ${ }^{2}$ C. Pinto, ${ }^{4}$ K. Martins, ${ }^{5}$ T. Guérin, ${ }^{3}$ A. Azevedo ${ }^{1}$ \\ * Corresponding author, afortunato@Inec.pt
}

Submitted: May 24, 2021; reviewed: July 25, 2021; accepted: July 27, 2021; available online: July 30, 2021

This is a post-peer-review, pre-copyedit version of an article published in Marine Geology. The final authenticated version is available online at: https://doi.org/10.1016/j.margeo.2021.106590. Please cite this paper as:

Fortunato, A.B., P. Freire, B. Mengual, X. Bertin, C. Pinto, K. Martins, T. Guérin, A. Azevedo 2021.Sediment dynamics and morphological evolution in the Tagus Estuary inlet, Marine Geology, 440: 106590. DOI: 10.1016/j.margeo.2021.106590

\section{Abstract}

The morphological evolution of the Tagus estuary inlet in the last century is analyzed in order to characterize its dynamics, explain its behavior and anticipate its future evolution. First, the evolution is characterized through a literature review, complemented by new data analyses. This review synthesizes the present understanding of the inlet's dynamics and highlights some key questions that remain unanswered. To address these questions, a $2 \mathrm{DH}$ process-based morphodynamic model is implemented and validated, and then used to refine the previous understanding of the inlet's dynamics. A new conceptual model, which highlights a seasonal behaviour of the inlet's morphodynamics, is proposed. During winter time, the residual sediment transport is directed seaward along the navigation channel, towards the inlet mouth along the beaches adjacent to the inlet, and towards the estuary over the southern part of the ebb delta (Cachopo Sul). During the maritime summer, residual sediment fluxes are approximately half those occurring during winter. The relative importance of tidal flows increases, leading to sediment fluxes directed towards the southwest over the Cachopo Sul. The sediment deposits formed during the summer can be mobilized under specific wave conditions and transported to the northern stretch of the beaches to the south of the inlet. A positive feedback between the erosion of the Cachopo Sul - or, similarly, sea level rise - and the sediment fluxes over this bank suggests that the evolution of the bank observed during the last decades will continue in the foreseeable future.

Keywords: morphodynamics, process-based model, data analysis, SCHISM

\footnotetext{
${ }^{1}$ National Laboratory for Civil Engineering, Av. do Brasil, 101, 1700-066 Lisbon, Portugal (\{afortunato, pfreire, aazevedo\}@Inec.pt)

${ }^{2}$ UMR 7266 LIENSs, La Rochelle Université, CNRS, 2 Rue Olympe Gouges, F-17000 La Rochelle, France (xbertin@univ-Ir.fr)

${ }^{3}$ Now at SAS Benoit Waeles - Consultant Génie Côtier, 53 rue du Commandant Groix, 29200 Brest, France (baptiste.mengual@bw-cgc.fr)

${ }^{4}$ Agência Portuguesa do Ambiente, Rua da Murgueira n. ${ }^{\circ}$ 9, 2610-124 Amadora, Portugal (celso.pinto@apambiente.pt)

${ }^{5}$ UMR 5805 EPOC, CNRS - Université de Bordeaux, Allée Geoffroy Saint-Hilaire, F-33615 Pessac, France (kevin.martins@u-bordeaux.fr)
} 


\section{Introduction}

Tidal inlets, loosely defined as the entrance to estuaries or lagoons, comprise flood and ebb tidal deltas, and a throat through which tidal currents flow along one or more channels. Tidal inlets control therefore the exchanges of water and water-borne material between estuaries and the coastal oceans. The morphology of the inlets can significantly affect tidal propagation (Aubrey and Speer, 1985, Oliveira et al., 2006; Araújo et al., 2008; Gong et al., 2009), salinity and temperature (Panda et al., 2013, Garcia-Oliva et al., 2019), larvae (Brown et al., 2000), and residence times (Oliveira et al., 2007; Renteria and Chirino, 2019) inside the estuaries. In addition, since many large estuaries shelter important harbors, the morphology of inlets can constrain the navigation routes to and from the estuaries. Hence, the maintenance of navigation channels with adequate depths and stable locations is often required, through jetties or dredging operations. Finally, the intense sediment dynamics at tidal inlets can affect the adjacent coast (Fitzgerald, 1984). Because these dynamics result from a delicate balance between tidal and wave action, tidal inlets can act alternately as sources and sinks of sediments (Nahon et al., 2019). The morphological evolution of tidal inlets and the adjacent beaches is thus often closely linked.

This importance of the morphological state of tidal inlets on water levels, water quality and navigation has fueled many studies over the years. During the $20^{\text {th }}$ century, these studies were primarily based on empirical models, classifications and descriptions (e.g., O`Brien, 1969; Jarrett, 1976; Hayes, 1979; Hubbard et al., 1979). Although these approaches met with significant successes, their limitations stand out when the morphology of a specific inlet deviates significantly from the norm, for instance due to geological or anthropogenic constraints. In such cases, recognizing the characteristic elements of tidal inlets and inferring morphological behaviors from similar inlets can be difficult. Over the past two decades, process-based models (Lesser et al., 2004; Warner et al., 2008; Bertin et al.; 2009a, Franz et al., 2017) have progressively emerged as reliable alternatives, that can reproduce the behavior of both empirical models (Nahon et al., 2012; Tran et al., 2012) and observations (Cayocca, 2001; Bruneau et al., 2011). These models are used to analyze physical processes (Bertin et al., 2009b; Elias and Hansen, 2013; Dodet et al., 2013), anticipate the impact of climate change (Bruneau et al., 2011; Duong et al. 2017), and assess engineering interventions (Mendes et al., 2016; VelasquezMontoya, 2020). Process-based models are particularly useful in data-poor environments and in morphologically complex systems. Still, considering the remaining limitations of the process-based models (e.g., Bertin et al., 2019), their application should generally be supported and complemented by data analyses.

The Tagus Estuary (Portugal; Figure 1), one of the largest European estuaries, concentrates many of the issues summarized above. The bar of the inlet channel requires frequent dredging to guarantee good navigation conditions (Oliveira, 1993). To the south of the inlet, the beaches of the Caparica coast have suffered frequent erosive episodes (Pinto et al., 2007; Veloso Gomes et al., 2009). Although they are protected by hard structures constructed between the late 1950's and the early 1970 's, they had to be nourished with 4.5 million cubic meters of sand between 2007 and 2019 ( $0.5 \mathrm{M}$ in 2007 and $1 \mathrm{M}$ in 2008, 2009, 2014 and 2019) to defend the existing coastal protection structures, mitigate coastal erosion and coastal overwash and, if possible, increase the beach width for recreational use. Finally, inundation and overtopping episodes have occurred along the margins during extreme storms (e.g., during the 2014 Hercules storm, Silva et al., 2017), causing alarm as mean sea level continues to rise.

In spite of the economic and environmental implications of the sediment dynamics in the Tagus inlet, the understanding of this dynamics remains sketchy and qualitative. Existing studies are scarce and based on data analyses alone (e.g., Oliveira, 1993; Lira and Taborda, 2014). Significant knowledge gaps remain on the sediment pathways, the causes of the observed evolution and the impact of climate change. A more detailed and quantitative understanding of the sediment dynamics is therefore needed to support informed management decisions by the water, environment and harbor authorities, and to inform the populations directly at risk. The work described herein aims at filling these knowledge gaps. More generally, this study provides new insights on the morphodynamics of highly-dynamic estuarine environments subject to various forcings, with the identification of the main drivers of the 
hydro-sedimentary dynamics and the assessment of their present and future evolution in a sea level rise context.

This paper is organized as follows. First, the inlet morphodynamics is analyzed through available data and literature (Section 2). Then a process-based numerical model is implemented and validated (Section 3), and applied to further investigate remaining knowledge gaps (Section 4). Section 5 summarizes the main conclusions.

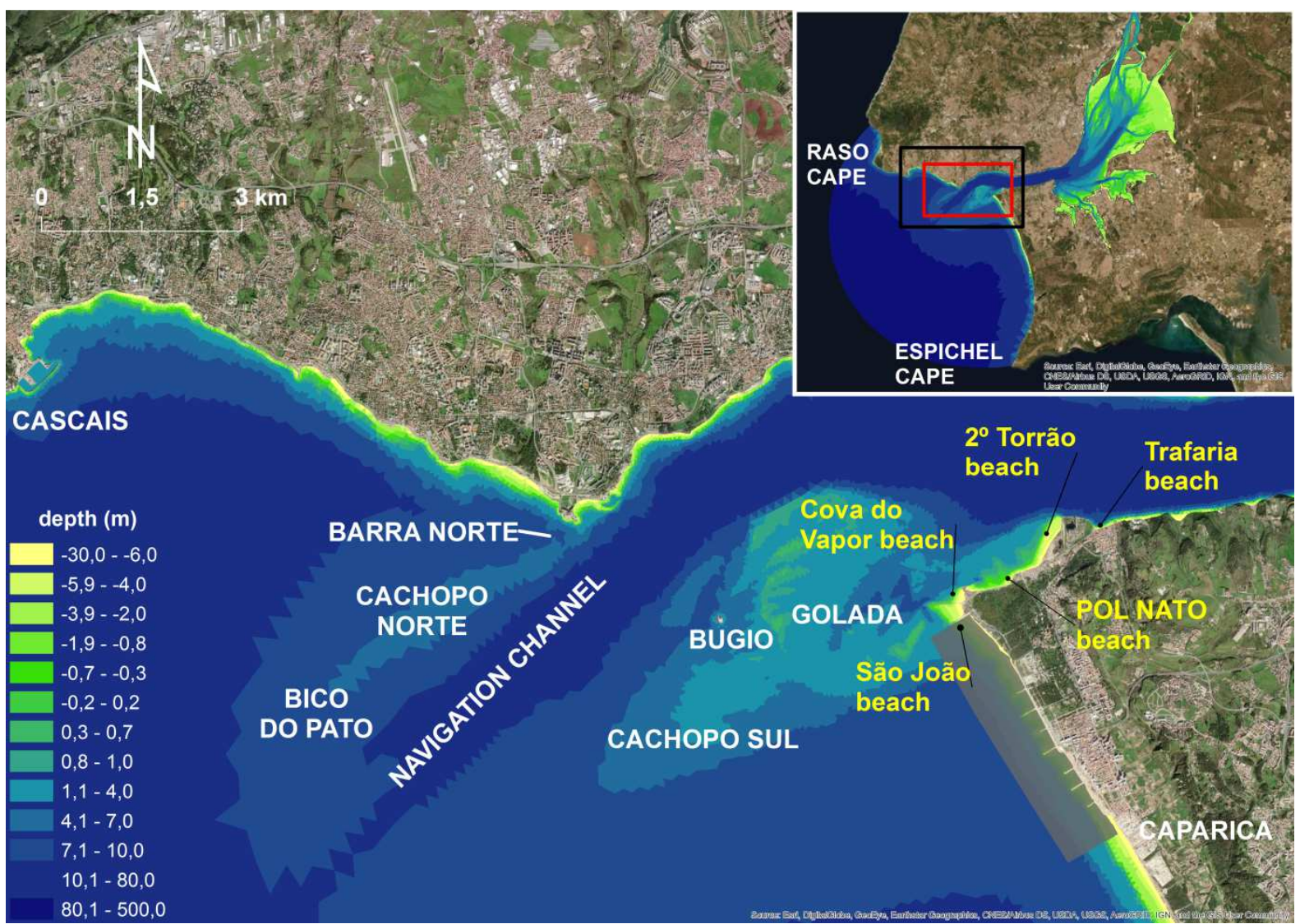

Figure 1. Tagus Estuary (Portugal): location, place names and present bathymetry relative to the chart datum. The grey-shaded area represents the monitored zone of the Caparica coast. The red rectangle indicates the area used for the analysis of the model results (figures $8,10,11,13$ and 14)

\section{Site description}

\subsection{Morphology and long-term evolution}

\section{Morphology}

The Tagus Estuary morphology is characterized by a wide and shallow inner bay, where tidal flats represent about $40 \%$ of the total estuarine area, and a narrow and deep fault-controlled channel that connects the inner and the outer estuarine domains (Figure 1). The estuarine inlet is located in a wide bay limited by conspicuous rocky points (the Raso and Espichel capes in the North and South, respectively). To the north of the inlet, the coast has a WNW-ESE orientation, and is formed by a combination of rocky shores and small pocket and crenulated-shape beaches. Sediment sources are insignificant, and the littoral transport is negligible due to the sheltering effect of the Raso Cape on the most frequent wave directions. South of the inlet, the coastline evolves in a NW-SE crescenticshape beach, $24 \mathrm{~km}$ long. Along the $5 \mathrm{~km}$ stretch to the south of Cova do Vapor, the coastline presents an alluvial plain with strong anthropogenic occupation. This stretch has suffered from severe sediment 
starvation for the last 60 years, which motivated the construction of coastal protection structures and several artificial sand nourishments.

The Tagus Estuary inlet presents a morphological organization typical of a mesotidal ebb-tidal delta. The contrasts between the adjacent coastlines, seabed morphologies and the incident waves obliquity, promotes a pronounced asymmetry of the inlet that includes the following main morphological elements (Figure 1): 1) the main (navigation) channel, oriented NE-SW, with minimum depths of 1516 m regularly maintained by dredging at its seaward extremity; 2) a NW marginal bank (Cachopo Norte) with an elongated shape whose terminal lobe bends towards south-west (Bico do Pato), separated from the northern coastline by a secondary flood channel (Barra Norte); 3) a SW marginal bank (Cachopo Sul), presenting supratidal areas; and 4) a secondary channel (Golada) extending towards north-west between the Cachopo Sul bank and the southern coastline.

\section{Long-term evolution}

Based on historical data, Santos et al. (2017) points out that, in general, the morphological inlet organization was stable over the last 500 years, until the end of the 1930's. Nautical charts from 1857, 1878, 1909 and 1939 consistently show the Cachopo Sul as a roughly $3 \mathrm{~km}$ long sand spit anchored at the Cova do Vapor (Figure 2a-d). The $2 \mathrm{~km}$ stretch between the western tip of this spit and the Bugio lighthouse was shallow and included several islands that evolved over the years. However, in 1954 the situation had changed dramatically. The western tip sand spit had receded by over $1 \mathrm{~km}$, leaving behind some isolated islands (Figure 2e). This erosive trend continued during the second half of the $20^{\text {th }}$ century. For instance, the dune along the Caparica coast retreated by about $100 \mathrm{~m}$ between 1957 and 1963, and its height decreased by $6 \mathrm{~m}$ (Barceló, 1970). The erosion of the Cachopo Sul later led to the damage of the Bugio Fortress, which had to be protected from waves (Oliveira et al., 2000).
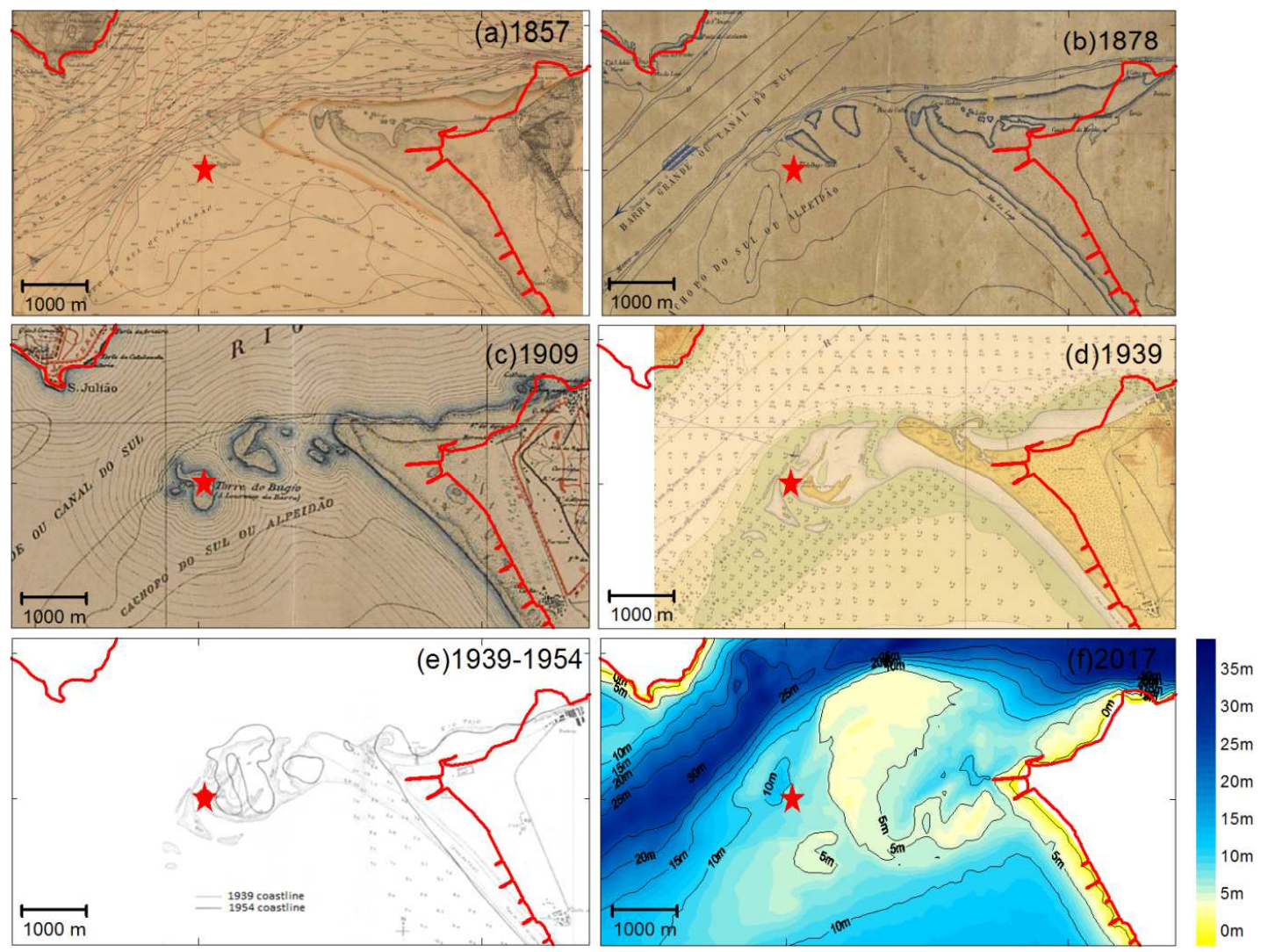

Figure 2. Evolution of the Cachopo Sul: a) 1857; b) 1878; c) 1909; d) 1929, updated in 1939 (adapted from Almada Virtual Museum, https://almada-virtual-museum.blogspot.com); e) 1939 and 1954 (extracted from Barceló, 1970, adapted from DGSL, 1955); f) 2017. The red stars indicate the position of the Bugio fortress, and the red line is the model boundary. 
The cause of this abrupt change in the morphology of the inlet between 1939 and 1954 remains unclear. An aerial photograph from 1947 indicates that the changes occurred mostly between 1947 and 1954 (Baptista Lopes, 1956). Silva (2013) attributed the erosion trigger to the dredging of 10 million $\mathrm{m}^{3}$ of sand from the Cachopo Sul at the end of the 1940's, but did not provide any evidence for this figure, which appears very high for the technical means available at the time.

\subsection{Present sediment dynamics}

\section{Sediment dynamics in the Cachopo Sul}

Qualitatively, sediments in the Tagus inlet are expelled from the estuary along the navigation channel, and return over the Cachopo Sul (Oliveira, 1973). The bedforms observed in a 2 m-resolution bathymetry provide a more detailed picture of the direction of these residual fluxes over the Cachopo Sul. Because this sand bank exhibits hydraulic dunes, the gradient of the steepest side of these bedforms indicates the sediment flux direction. (Error! Reference source not found.) The determination of the direction of residual sediment transport by the lee face orientation of bedforms was previously followed by other authors (Billy et al., 2012; Barnard et al., 2013). Between 1947 and 1985, these fluxes over the Cachopo Sul eroded this bank and promoted its northward extension at about $15 \mathrm{~m} /$ year (Oliveira, 1993). This trend continues presently. A comparison of bathymetries between 1997 and 2015 shows a strong erosion of this bank and the deposition of sediments in its northern and western slopes (Figure 4). The northward extension of the bank during this period varies between 10 and $20 \mathrm{~m} /$ year. This behavior is consistent with the need to dredge the northern flank of the bank in 2008. Simultaneously, this erosion increases the fraction of the tidal prism that flows over the Cachopo Sul, thereby weakening the ebb jet through the navigation channel and allowing the southward rotation of the terminal lobe of the Cachopo Norte due to wave action (Oliveira, 1993).

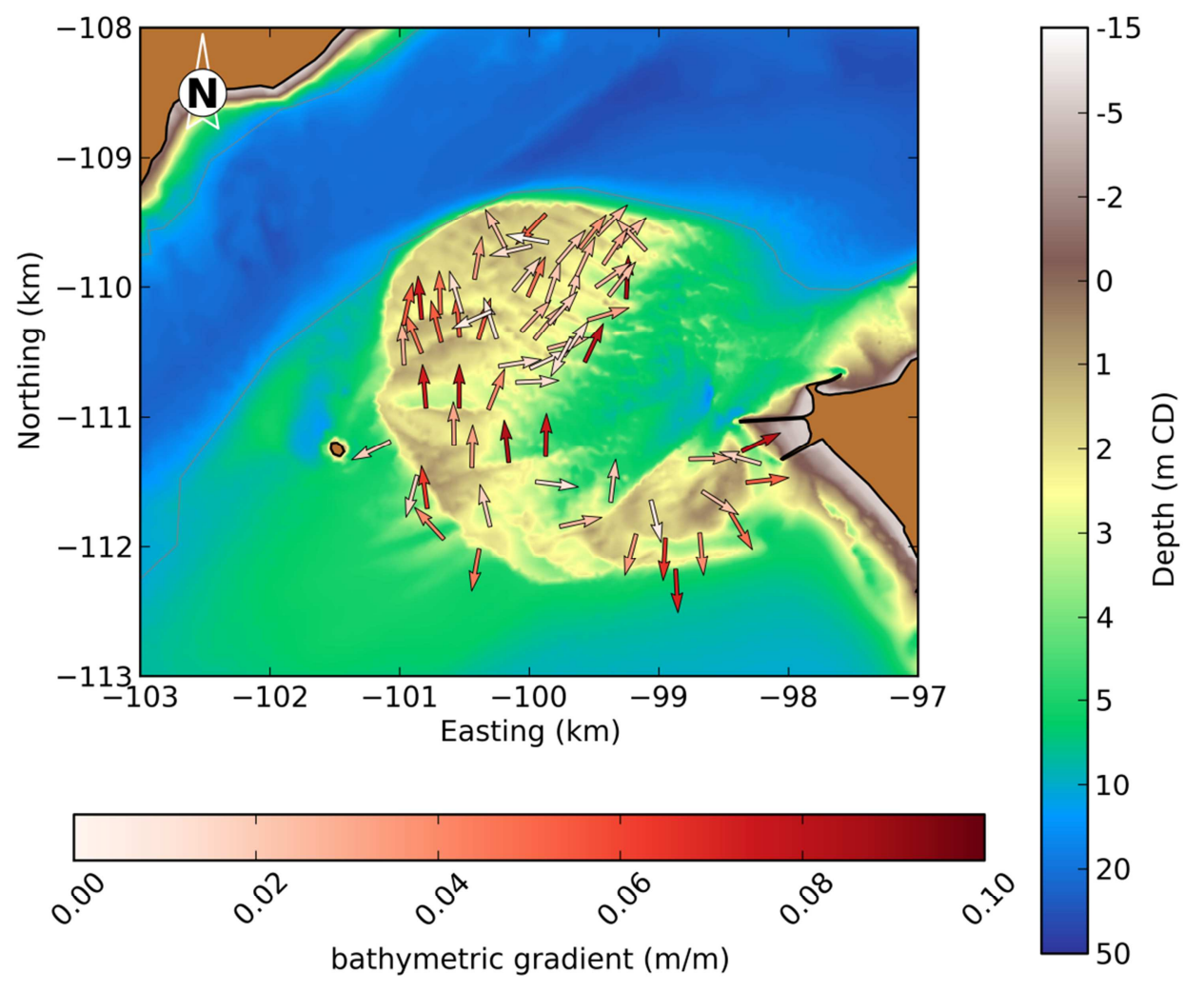

Figure 3. Bathymetry of the tidal inlet in 2018 relative to the chart datum (CD). The arrows indicate the largest gradients of the bed forms over the Cachopo Sul and the presumed direction of the residual sediment fluxes. 

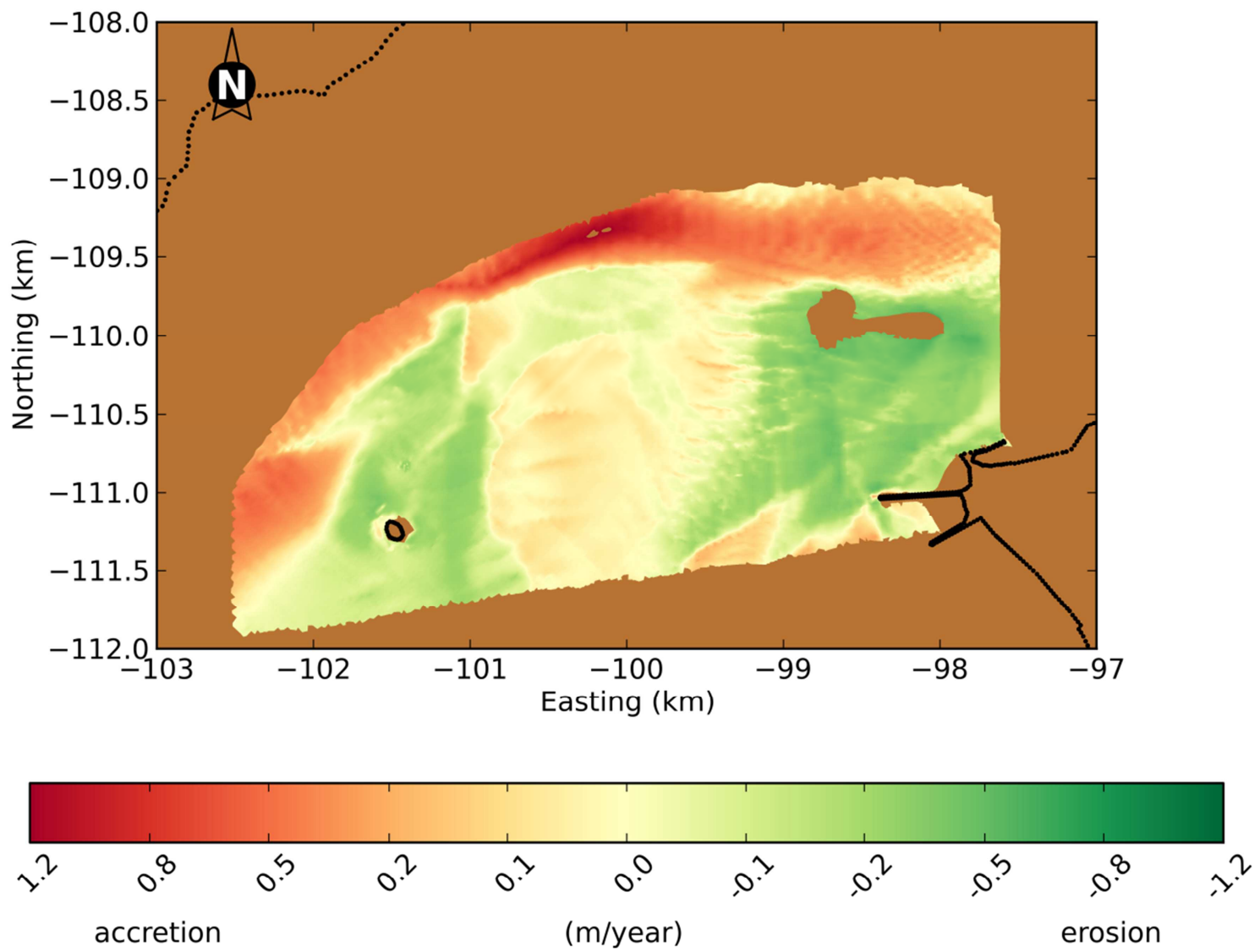

Figure 4. Erosion rates in the Cachopo Sul between September 1997 and September 2015.

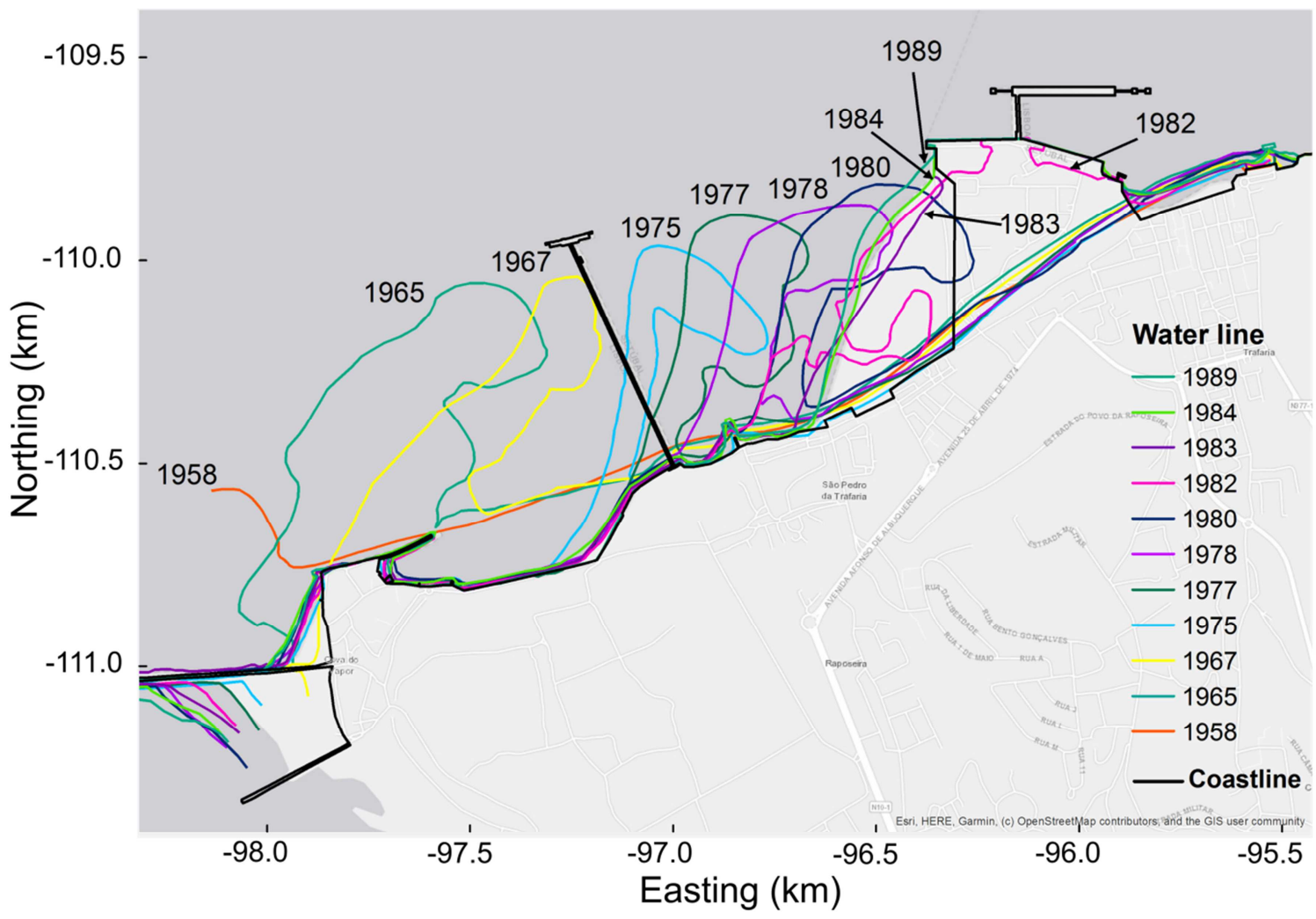

Figure 5. Evolution of the water line between Cova do Vapor and Trafaria in the period 1958-1989. 
The erosion of the Cachopo Sul results from two distinct types of sediment motion. First, a northward transport causes the extension of the bank mentioned above. Secondly, a movement of emerged banks towards the northeast has also been identified. Using data from bathymetric surveys between 1989 and 1996, Oliveira et al. (2000) showed that a bank above lower low water migrated to the northeast. Aerial photographs from 1958 and satellite images from 1973 to 2002 showed that this migration pattern is discontinuous but persistent (Lira and Taborda, 2014). Aerial photographs between 1958 and 1989 confirm these findings, showing the eastward migration of a sandspit attached to the Cova do Vapor at about $90 \mathrm{~m} /$ year (Figure 5).

\section{Sediment dynamics in the Caparica coast}

To the south of the inlet, the retreat of the Caparica coastline has been associated with the littoral drift. At Cova do Vapor, the sediment fluxes directed to the northwest are lost to the estuary and are generally not replaced by sediments coming from the estuary. While the littoral drift along the western Portuguese coast is directed southward (Silva et al., 2012), two effects explain the opposite direction in the northern stretch of the Caparica coast: 1) the Raso Cape shelters this stretch from the waves coming from the north-western sector and 2) waves refract over the Cachopo Sul, rotating northward. To prevent further erosion of the Caparica Coast, several groins and longitudinal structures were built between 1959 and 1971 (Veloso Gomes et al., 2006, 2009), and refurbished between 2004 and 2006. From 2001 onwards, the Caparica coast beaches were also artificially nourished (Veloso Gomes et al., 2006).

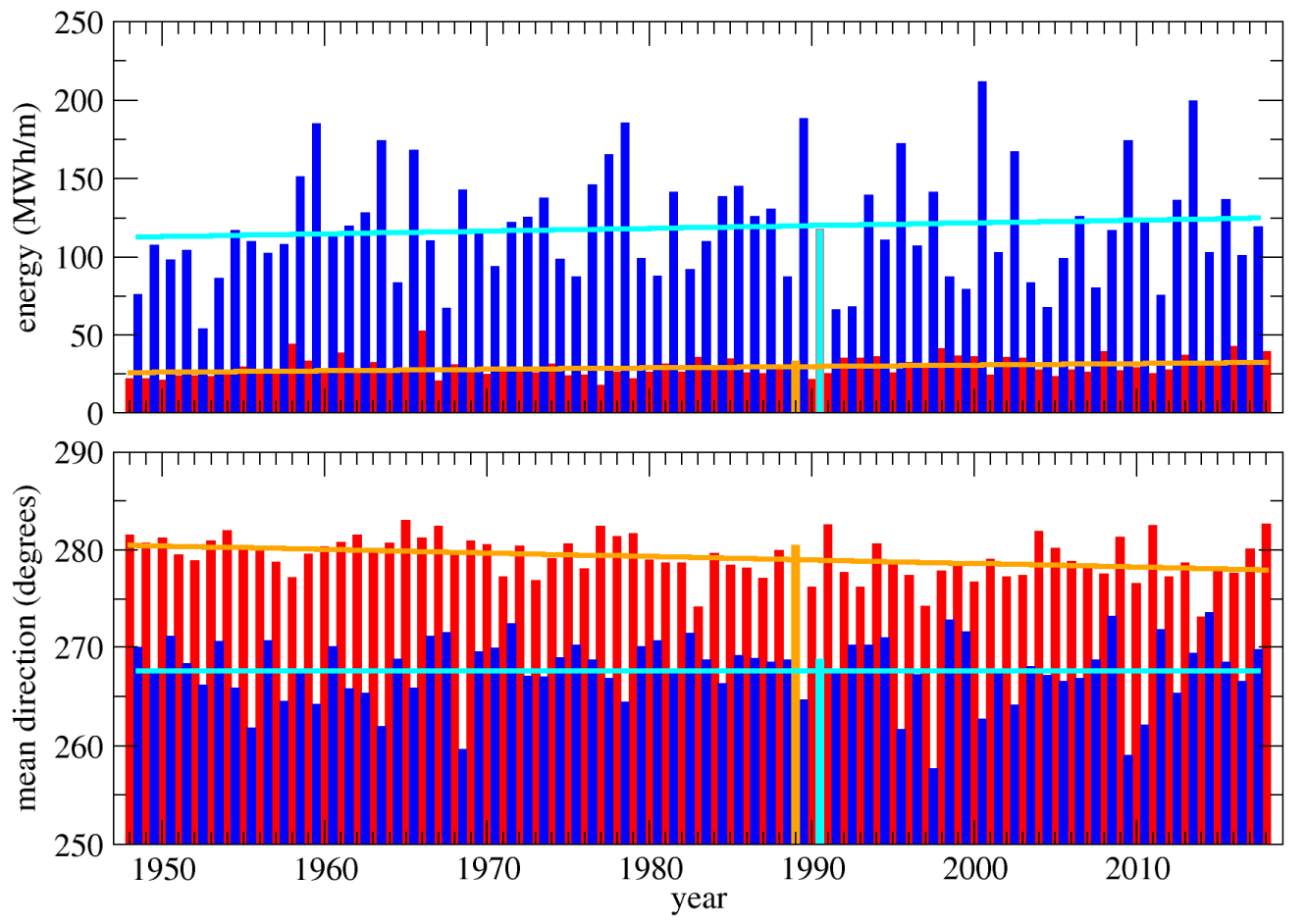

Figure 6. Characteristics of waves in front of the Tagus Estuary between 1948 and 2018 during the maritime summer (red) and the maritime winter (blue). The winter and summer periods selected for the simulations are shown in orange and cyan. The straight lines are linear regressions. Data are taken at the location of the wave buoy from a hindcast simulation using WaveWatch III and WWM forced by NCEP winds. In the evaluation of the mean directions, the directions are weighed by the wave power.

The retreat of the Caparica coastline over the past decades decreases southward (Veloso Gomes et al., 2009; Lira et al., 2016). This retreat of the northern stretch of the Caparica coast translates into a clockwise rotation of the coastline. Assuming the beaches were close to equilibrium until the late 1930 's, this rotation of the coastline should have increased the obliquity of the waves and the northward transport along the beach. The increase of the littoral drift would grow northward, leading 
to a flux divergence and to the erosion of the beach. Hence, erosion would tend to increase due to a positive feedback. Furthermore, previous studies indicate that the wave climate has been changing in the North Atlantic (Bertin et al., 2013). In order to verify if these changes could contribute to the evolution of the Cachopo Sul, hindcasts of waves in the North Atlantic were performed for 19482018. Simulations were performed with the model WaveWatch III forced by NCEP reanalyses (Moreira et al., 2019), followed by a nested simulation with the coupled SCHISM-WWM model. The nested simulation is similar to the Tagus estuary model that is described below. Results show an increase in the wave energy of $11 \%$ in the winter and $25 \%$ in the summer in front of the Tagus inlet (Figure 6), which should also increase the littoral drift along the Caparica beaches.

\section{Sediment exchanges between the Cachopo Sul and the Caparica coast}

Although the evolution of the Cachopo Sul and the Caparica coast are expected to be closely linked, the sediment exchanges between them are unclear. In order to identify the fate of the sediments used in the beach nourishments, a $4 \mathrm{~km}^{2}$ area in the Caparica coast was monitored between 2007 and 2018, from the dune to depths of about $10 \mathrm{~m}$ below mean sea level (Figure 1). Monitoring results show a nonlinear evolutionary pattern related to the intrinsic variability of the system, characterized by a well-marked seasonality, and hint at complex sediment exchanges between the Caparica coast beaches and the Tagus ebb-delta (Pinto et al., 2014, 2015, 2020). The Cachopo Sul lost 900,000 $\mathrm{m}^{3}$ of sand between September 2009 and September 2010, while the monitored area gained 1,700,000 $\mathrm{m}^{3}$ between July 2009 and May 2010, which includes 1 million $\mathrm{m}^{3}$ of nourished sand (Pinto et al., 2014). The coincidence between the erosion of the Cachopo Sul and the natural sedimentation of the Caparica coast suggested that the Cachopo Sul provided large volumes of sediments to the beach and the shoreface of Caparica. This process could justify, in some situations, the observed positive sediment budget in the Caparica beaches and adjacent shoreface, and contribute to the stabilization and greater protection in this area, namely if the exchanges occur in the eastward direction. For instance, the monitored area gained $680,000 \mathrm{~m}^{3}$ of sand between June 2013 and July 2014. This behavior is particularly surprising because the 2013-2014 Winter was exceptionally energetic, and most Portuguese beaches (including Caparica) suffered strong erosion.

Several questions on the sediment dynamics of the Tagus Estuary inlet remain and will be addressed in the following sections. First, the existing conceptual model of the sediment dynamics (Oliveira, 1973; Taborda and Andrade, 2017) is sketchy, partly qualitative, and ignores the seasonal variability. Hence, a more detailed and quantitative understanding of the present sediment dynamics, including the dependence of the sediment fluxes on the wave characteristics and on the tidal range, is needed. Secondly, although the residual littoral transport along the northern stretch of the Caparica coast is directed towards the inlet, the analyses described above suggest that the Cachopo Sul may also provide sediments to the Caparica coast under some circumstances. This hypothesis should be analyzed and verified. Finally, the inlet has been experiencing a persistent erosion of the Cachopo Sul since the 1940's and it is unclear if it is approaching a new state of equilibrium. Furthermore, sea level rise will also increase the water depth over the Cachopo Sul, thus potentially enhancing the morphological evolution. Understanding how the Cachopo Sul will continue to evolve and whether it is moving towards a new equilibrium requires determining the feedback mechanisms between the erosion and the sediment fluxes over this bank.

\section{Numerical model}

\subsection{Model description}

\section{Hydrodynamics}

SCHISM (Semi-implicit Cross-scale Hydroscience Integrated System Model, Zhang et al. 2016) is a derivative product built from the original SELFE model (Zhang and Baptista, 2008), with many 
enhancements and upgrades including new extension to large-scale eddying regime and a seamless cross-scale capability from creek to ocean (Ye et al., 2020). Built around a core hydrodynamic module, SCHISM includes several modules for waves, morphodynamics, and water quality. The hydrodynamic module solves the shallow water equations in $2 \mathrm{DH}$ or $3 \mathrm{D}$, using a combination of finite element and finite volume techniques.

The wave module (Wind Wave Model, WWM-II; Roland et al., 2012) is fully coupled to the hydrodynamic module and solves the wave action equation to simulate the generation and transformation of short waves on the same horizontal grid as SCHISM. In 2DH, wave forces are represented with a radiation stress formalism (Longuet-Higgins and Stewart, 1962), which was extended to random wave spectra by Battjes (1974). At the numerical shoreline, a local balance between the free surface-induced barotropic pressure gradients and the wave forces is imposed in order to avoid non-physical and spurious current velocities induced by the presence of dry nodes at the corresponding elements. This approach allows for the computation of wave forces, current velocities and thus sediment fluxes up to very shallow waters (critical depth for wetting and drying taken as $0.01 \mathrm{~m}$ herein), without any additional numerical diffusion. Wave-induced bottom stresses are evaluated with the Grant and Madsen (1979) formulation.

\section{Sediment dynamics and bed evolution}

Sediment transport can be computed in depth-averaged or fully 3D mode. Simulations are performed here in $2 \mathrm{DH}$ mode since simulations in $3 \mathrm{D}$ mode proved to be too computationally demanding for extensive seasonal simulations. The errors introduced by this simplification are expected to be acceptable due to the relatively coarse, sandy sediments and the absence of stratification. First, the socalled SED2D module computes the sediment fluxes at each element center of the computational grid, by using a semi-empirical formulation (based on the properties of fluid, sediment and waves) which provides a total flux over the water column, sum of a bedload and a suspended-load flux. Semiempirical sediment transport formulae assume a local equilibrium between the hydrodynamics and the sediment fluxes. Although SED2D offers the option of several semi-empirical formulations, all the results presented herein were obtained with the $\mathrm{Wu}$ and $\mathrm{Lin}$ (2014) formula. This sediment transport computation can be configured in a multi-class and multi-layer mode, i.e. accounting for the heterogeneity of the sediment grain size (Guérin et al., 2016a), based on the approach of Reniers et al. (2013). In the latter case the sediment transport is computed for each grain size class and weighted by its associated fraction present in the surface layer of the sediment column, after which the transport is summed over all grain size classes. The formulation of $\mathrm{Wu}$ and Lin (2014) allows accounting for the effect of wave asymmetry on the associated wave-averaged sediment transport under combined waves and currents. The method of Elfrink et al. (2006) is used to determine the maximum and minimum orbital bottom velocity under the wave crest and trough, respectively, as well as the two associated half wave periods (see Fig. 1 of Wu and Lin (2014) for the corresponding sketch). These parameters are computed from bulk wave parameters (i.e., significant wave height, peak period), water depth and local bottom slope. These four parameters characterizing the asymmetric wave profile are then used in the $\mathrm{Wu}$ and Lin (2014) formulation to obtain the bed shear stress under combined waves and currents (see their Eqs. 17-23), and eventually the associated sediment transport (see their Eqs. 27-29).

Following sediment flux computations, the bed compartment properties (thickness and composition of sediment layers) and the water depth are updated. The upper layer is merged with the one just below or split in two if it exceeds user-specified thresholds (Warner et al., 2008). Bed changes are computed by solving the sediment continuity/Exner equation with a Weighted Essentially Non-Oscillatory (WENO) scheme that prevents the development of numerical oscillations in the bed without adding artificial diffusion or bathymetric filters (Guérin et al., 2016b). The model is run in morphodynamic mode, meaning that water depth changes resulting from sediment dynamics are fed back to the circulation and wave modules. 


\subsection{Model application and validation}

\section{Hydrodynamics}

The model implementation evolved from the application of Fortunato et al. (2017a), with an improved description of the boundary in the coastal area (Figure 7). The grid covers the whole estuary and extends $28 \mathrm{~km}$ into the Atlantic Ocean. The grid resolution varies between 10 and $50 \mathrm{~m}$ at the tidal inlet, and about $2 \mathrm{~km}$ at the ocean boundary. The model is forced by tides and waves from the regional models of Fortunato et al. (2016) and Fortunato et al. (2017b), respectively, atmospheric pressure and wind from the ERA-INTERIM reanalyses (Dee et al., 2011), and a constant river discharge. The model is run in barotropic mode, since the Tagus estuary is usually well-mixed (Rodrigues et al., 2019).

The physical and numerical parameters were based on previous applications of SCHISM to the Tagus Estuary in which extensive calibrations and sensitivity analyses were performed (Guerreiro et al., 2015; Rodrigues and Fortunato, 2017; Fortunato et al., 2017a). The model was not further calibrated, as the physical and numerical parameters are expected to remain valid. The circulation module was validated against elevations measured in 1972 at thirteen tide gauges throughout the estuary, and wave data measured outside the estuary in the fall 2011 (see Figure 7 for gauge locations). Tidal propagation is reproduced with root-mean square errors between $5 \mathrm{~cm}$ (at the coast outside the estuary) and up to $18 \mathrm{~cm}$ in the upper estuary (Table 1). This accuracy is similar to the one obtained in previous model applications in the Tagus Estuary (e.g., Fortunato et al., 2017a, Rodrigues et al., 2019). The wave module was validated for an energetic period (October-December 2011), when the significant wave height and the peak period reached $5 \mathrm{~m}$ and $22 \mathrm{~s}$, respectively. The present Tagus model is more accurate than the regional model used to provide boundary conditions (Table 2), probably due to the higher resolution and to the consideration of the interaction between the tides and the waves.
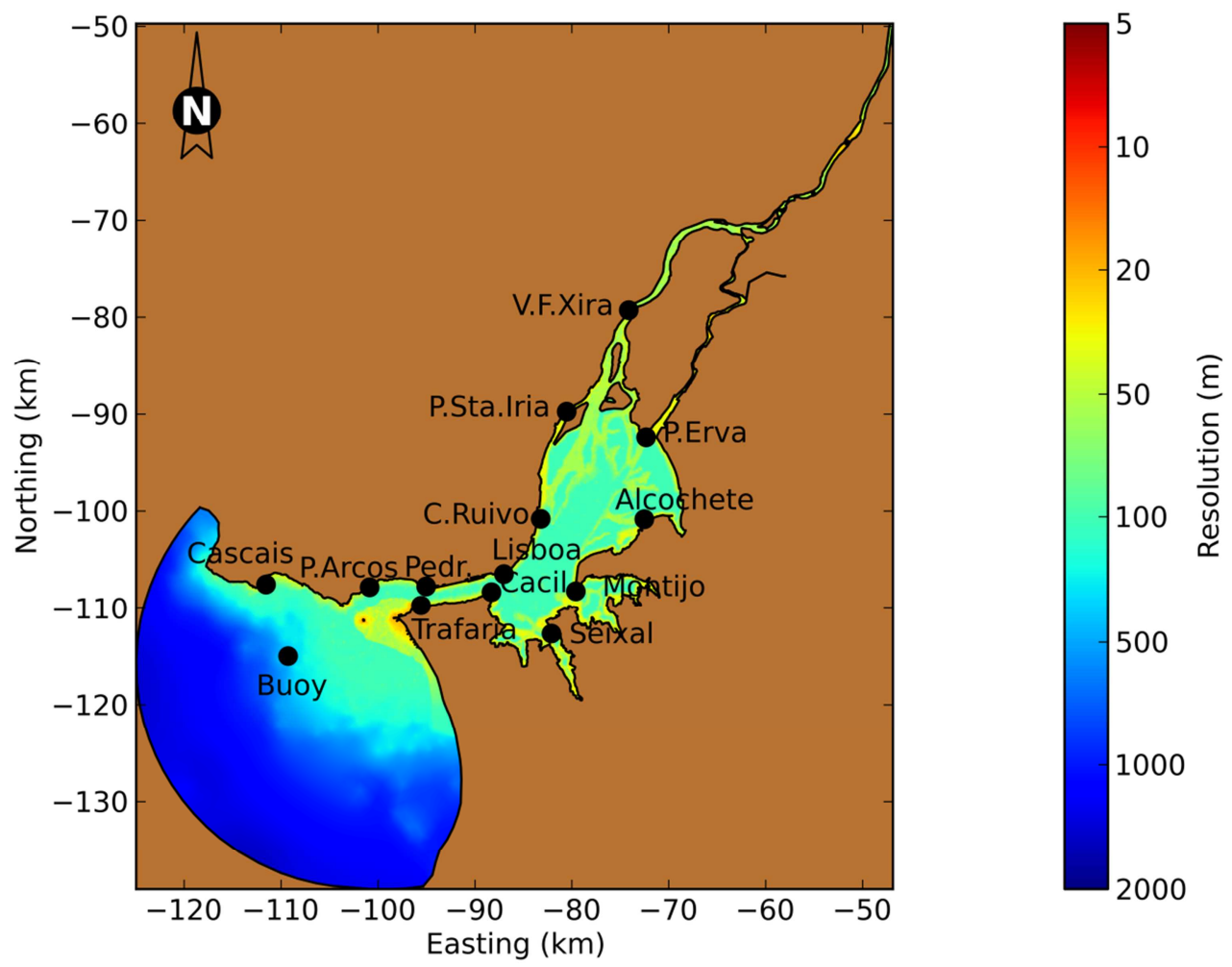

Figure 7. Model domain and grid resolution, given by the equivalent element diameter. The green circles indicate the locations of the tidal gauges (along the margins) and the APL wave buoy (in front of the inlet) used for model validation 
Table 1. Validation of the tidal model: root-mean square errors (RMS) and unbiased root-mean square errors (URMS). The tidal stations are shown on Figure 7

\begin{tabular}{lcc}
\hline Station & RMS (m) & URMS (m) \\
\hline Cascais & 4.6 & 4.6 \\
P. Arcos & 6.4 & 3.7 \\
Trafaria & 10.2 & 6.4 \\
Lisboa & 10.0 & 4.0 \\
Pedrouços & 6.0 & 3.5 \\
Cacilhas & 4.7 & 4.2 \\
Seixal & 7.6 & 5.2 \\
Montijo & 10.9 & 4.5 \\
C. Ruivo & 12.3 & 5.2 \\
Alcochete & 9.1 & 8.5 \\
P. Sta. Iria & 13.5 & 11.2 \\
Pta. Erva & 18.1 & 16.8 \\
V.F. Xira & 15.3 & 9.9 \\
\hline
\end{tabular}

Table 2. Validation of the wave models with data from October-December 2011: root-mean square errors (RMS), normalized root-mean square errors (NRMS) and biases. NRMS are normalized by the mean of the data. The buoy location is shown on Figure 7

\begin{tabular}{l|cccccccc}
\hline \multirow{2}{*}{ Model } & \multicolumn{3}{|c}{ Significant wave height } & \multicolumn{3}{c}{ Peak period } & \multicolumn{2}{c}{ Mean direction } \\
RMS & NRMS & Bias & RMS & NRMS \\
$(\mathrm{m})$ & $(-)$ & $(\mathrm{m})$ & $(\mathrm{s})$ & $(-)$ & $\begin{array}{c}\text { Bias } \\
(\mathrm{s})\end{array}$ & $\begin{array}{c}\text { RMS } \\
(\text { degrees })\end{array}$ & $\begin{array}{c}\text { Bias } \\
(\text { degrees })\end{array}$ \\
\hline \multirow{3}{*}{ Regional model } & & & & & & & & \\
Tagus model & 0.32 & 0.20 & 0.23 & 1.3 & 0.11 & -0.49 & 12.7 & 10.3 \\
\hline
\end{tabular}

\section{Sediment dynamics and bed evolution}

The morphodynamic module was run with five sediment classes (Table 3), which were determined based on field data (see Appendix). The spatial distribution of the sediments was initially uniform, but evolved during the simulation. A sensitivity analysis of the two transport formulae that provided the best results in Guérin et al. (2016a) (van Rijn et al., 2004, and Wu and Lin, 2014 - both allowing for multi-sized sediments) showed that the latter offered the results most consistent with the existing understanding of the sediment fluxes in this area. All simulations shown herein are therefore obtained with the $\mathrm{Wu}$ and Lin (2014) formulation. Note that the hiding and exposure mechanism, which is an inherent characteristic of heterogeneous sediment transport, is included in this formulation.

Table 3. Sediment classes and fractions used in the model

\begin{tabular}{l|ccccc}
\hline Diameter $(\mathrm{mm})$ & 0.15 & 0.25 & 0.30 & 0.35 & 0.45 \\
\hline Fraction $(-)$ & 0.1 & 0.25 & 0.3 & 0.25 & 0.1 \\
\hline
\end{tabular}

Simulations were performed for 6 months in order to analyze the sediment dynamics during the maritime winter and summer separately. The most representative periods to perform the simulations were selected through an analysis of the wave energy (per unit length of the wave crest) at seasonal scales (Figure 6). No morphological factor was used to speed-up the simulations. 

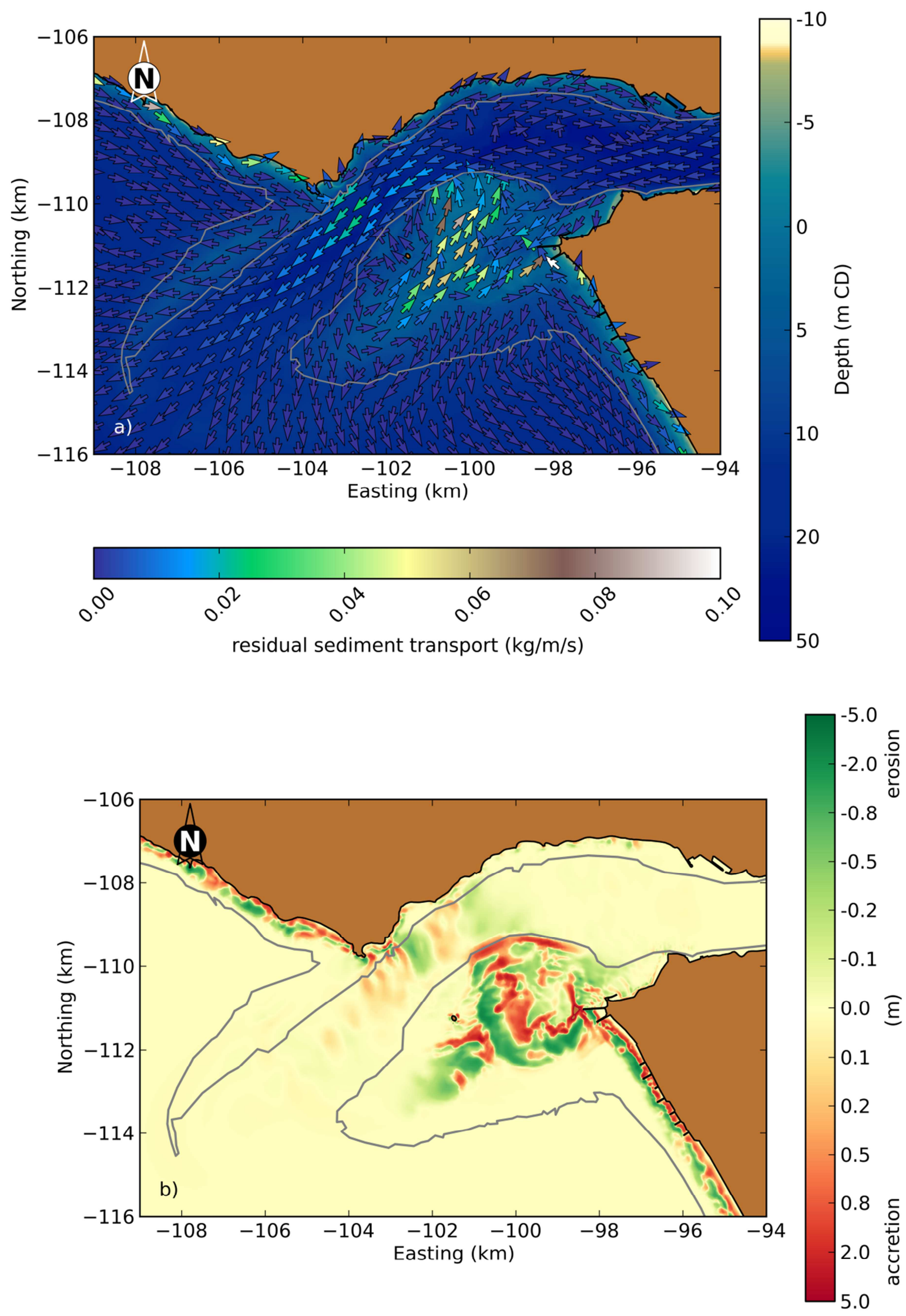

Figure 8. Morphodynamics of the Tagus Estuary inlet during a mean maritime winter (1990-1991): a) residual sediment fluxes; b) erosion/deposition patterns. 
Two simulations were performed to verify the model's ability to reproduce the known behavior of the system. First, a simulation for a maritime winter (1990-1991) representative of mean conditions (Figure 6) was performed. Residual (time-averaged) sediment fluxes (Figure 8a) are globally consistent with the empirical model of Oliveira (1973): sediments flow out of the estuary through the navigation channel and partly return over the Cachopo Sul. In more detail, the directions of the sediment fluxes are also consistent with the bedforms observed in a recent bathymetry (Error! Reference source not found.). Finally, in spite of more pronounced bed level changes, the modeled sediment deposition patterns (Figure 8b) also resemble the ones obtained from a comparison of bathymetric surveys (Figure 4). In particular, the model reproduces qualitatively the accretion at the northern flank and in the center of the Cachopo Sul, and the erosion in the western and eastern parts of the bank. Then, a second simulation was performed to test the model's ability to reproduce the eastward migration of emerged sandbanks observed in satellite images and consecutive bathymetries. The same simulation was repeated using a bathymetry in which a Gaussian-shaped idealized sandbank was introduced. After six months, the western part of the idealized sandbank had been eroded (Figure 9). The coordinates of the center of mass of the dune were computed as:

$$
(x, y)=\left(\frac{\iint h x d x d y}{\iint h d x d y}, \frac{\iint h y d x d y}{\iint h d x d y}\right)
$$

where $h$ is the difference between the bathymetry at the beginning or the end of the simulation and the measured bathymetry, and the integrals are performed over the initial position of the dune $(6 \mathrm{~m}$ contour in Figure 9). Results show that the center of mass of the dune migrated $19 \mathrm{~m}$ to the north-east, confirming the model's ability to reproduce the known morphological behavior of the inlet.

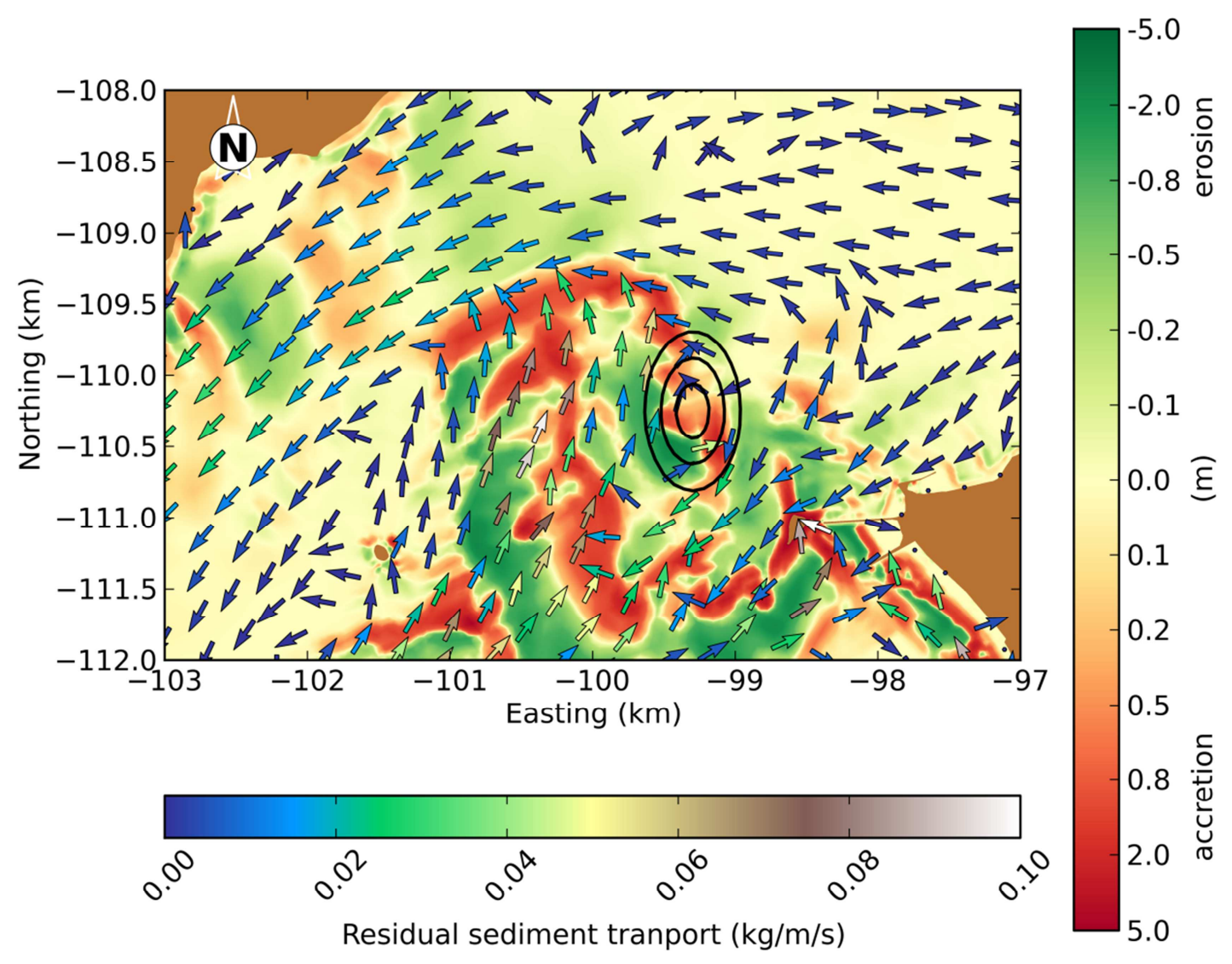

Figure 9. Validation of the morphodynamic module. The residual sediment fluxes and erosion/deposition patterns show the eastward movement of a hypothetic emerged sandbank. The bank, added to the original bathymetry, is indicated by its $2 \mathrm{~m}, 4 \mathrm{~m}$ and $6 \mathrm{~m}$ contours (black ellipses). 


\section{Model-based analysis of the inlet's dynamics}

\subsection{Role of forcing agents}

Sediment fluxes were first characterized through short simulations for different ocean boundary conditions (tidal amplitudes, significant wave height $\mathrm{Hs}$ and wave direction). The impact of river discharge was also briefly assessed and shown to be negligible. M2 tidal amplitudes of 0.3, 1.1 and $1.9 \mathrm{~m}$ were considered, to cover all the relevant tidal ranges. Wave conditions at the ocean boundary were set to 0, 2, 4 and $8 \mathrm{~m}(\mathrm{Hs})$, and directions from NW, W and SW (Table 4). These significant wave heights have exceedance probabilities of $100 \%, 37 \%, 2.7 \%$ and $0.01 \%$, respectively, according to the results from the hindcasts shown in Figure 6. The peak period was computed as a linear function of $\mathrm{Hs}$ based on a correlation determined from wave hindcast results. JONSWAP spectra were considered at the boundaries.

Table 4. Simulations used to characterize the sediment dynamics

\begin{tabular}{l|ccc}
\hline Simulation & Tidal amplitude $(m)$ & $H s(m)$ & Wave direction \\
\hline S1 & 0.3 & 0 & - \\
S2 & 1.1 & 0 & - \\
S3 & 1.9 & 0 & - \\
S4 & 1.1 & 2 & $\mathrm{~W}$ \\
S5 & 1.1 & 4 & $\mathrm{~W}$ \\
S6 & 1.1 & 8 & $\mathrm{~W}$ \\
S7 & 1.1 & 4 & $\mathrm{NW}$ \\
S8 & 1.1 & 4 & \\
\hline
\end{tabular}

Residual sediment fluxes increase by about two orders of magnitude from neap to mean tides, and an additional order of magnitude from mean to spring tides (Figure 10a-c). Tidally-driven residual sediment fluxes are directed seaward over the Cachopo Sul due to the strong ebb-dominance in this estuary (Fortunato et al., 1999). Since residual sediment transport is known to have the opposite direction (Oliveira, 1973, 1993, Error! Reference source not found.), this result suggests that wave action is generally dominant over this bank. Similarly, tides alone are unable to move sediments along the Caparica beaches. In the navigation channel, sediment fluxes are directed seaward due to the tidal currents. Firstly, extensive tidal flats (which occupy about $40 \%$ of the Tagus Estuary) cause ebbs to be shorter than floods (Fortunato and Oliveira, 2005). As a result, velocities are strongest on ebb in this estuary (Fortunato et al., 1999). Secondly, tidal pumping concentrates ebb flows in the main channel, and flood flows near the margins (Fortunato et al., 1997). This phenomenon also contributes to the seaward sediment fluxes in the navigation channel.

The changes in sediment fluxes with the growth of the significant wave height were analyzed through simulations S2 and S4-6 (Figure 10b, d-f). Waves with $\mathrm{Hs}=2 \mathrm{~m}$ have a modest effect on the residual fluxes: over part of the Cachopo Sul, sediment transport is directed northward, and along the Caparica beaches some fluxes are directed towards the estuary mouth. Waves coming from the west are refracted over the Cachopo Sul and rotate counter-clockwise. This rotation explains the direction of the littoral drift along the northern stretch of the Caparica coast. This mechanism was identified by Hayes (1979) and further detailed by Bertin et al. (2009b), who show how wave refraction around ebb deltas feeds sediments to tidal inlets. For $\mathrm{Hs}=4 \mathrm{~m}$, sediment transport becomes dominated by wave action outside the navigation channel. The residual sediment transport over the Cachopo Sul increases by an order of magnitude and becomes directed towards the estuary. Finally, for $\mathrm{Hs}=8 \mathrm{~m}$ the residual sediment fluxes increase by another order of magnitude. Along the Caparica beaches, offshore from the groins, a strong littoral drift towards the Cachopo Sul occurs. 

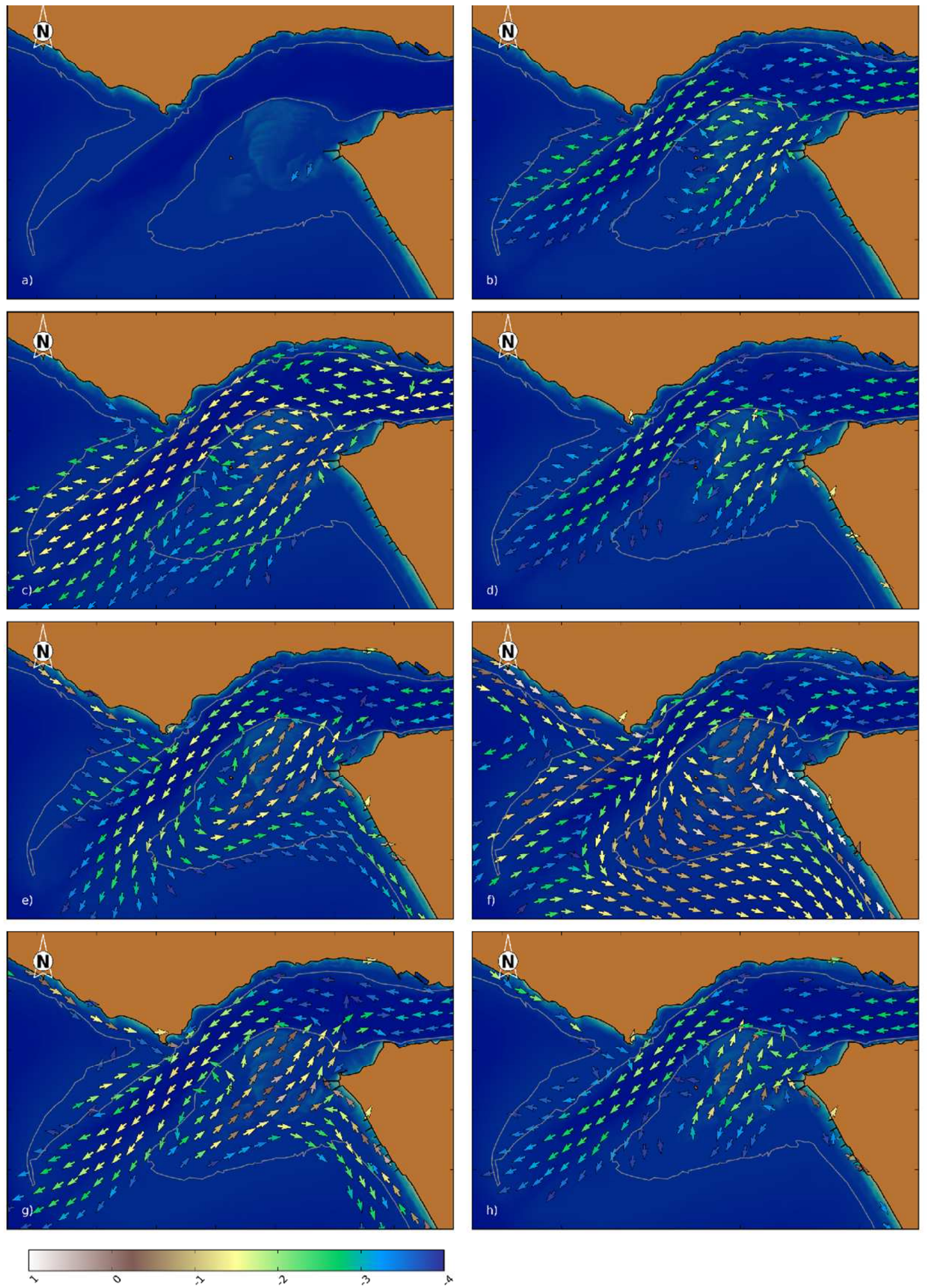

Log(residual sediment flux, in $\mathrm{kg} / \mathrm{m} / \mathrm{s}$ )

Figure 10. Residual sediment fluxes for simulation: a) S1; b) S2; c) S3; d) S4; e) S5; f) S6) g) S7; h) S8. See Table 4 for details on the simulations

The analysis of model results reveals that the inversion of residual sand fluxes over the ebb delta from offshore-directed to onshore-directed under energetic waves is primarily due to the development of 
onshore-directed flows, driven by the dissipation of short waves. Indeed, in contrast with the typical beaches with straight shorelines in which wave breaking-induced forces are balanced by the barotropic pressure gradient associated with the wave setup, the ebb delta of the Tagus Estuary Mouth mostly faces the entrance of the estuary, so that wave setup can hardly provide any balance with wave forces. Hence, wave breaking generates currents towards the inlet. This process was already analyzed in detail by Bertin et al. (2009b) at the shallow Óbidos Lagoon Inlet. However, unlike at shallow inlets where the ebb delta is partly intertidal, the subtidal ebb-delta of the Tagus Estuary mouth requires larger waves for depth-induced breaking to occur and generate these currents. Depending on the tidal phase, the wave threshold height can be 1 to $2 \mathrm{~m}$ at the seaward edge of the ebb-delta.

The dominant transport over the Cachopo Norte also switches direction, from tide-dominated (towards south-west) to wave-dominated (towards east-southeast). These results suggest that the rotation of this bank towards the inlet channel, identified by Oliveira (1993), is primarily driven by storm waves.

The offshore wave direction does not affect the order of magnitude of the sediment fluxes, but it has a significant impact on the sediment dynamics (Figure 10e,g,h). Waves coming from the south-west have the strongest impact due to their higher obliquity. The littoral drift is strong and directed towards the estuary mouth. The penetration of the longshore currents in the estuary enhances the ebb jet along the navigation channel. Waves coming from the west have a smaller obliquity and produce smaller sediment fluxes. The littoral drift is still directed towards the estuary mouth, but the waves are filtered by the Cachopo Sul and reach the coast with smaller wave heights. These trends are exacerbated for waves coming from the northwest. Waves in front of the Caparica beaches are smaller due to the protection provided by the Raso Cape and by the ebb delta. While for simulations S5 and S7 the values of Hs at the APL wave buoy (see Figure 7 for location) and offshore are similar, in simulation S8 Hs decreases by $25 \%$ from the model boundary to the wave buoy. Given the location of this buoy, this reduction is only due the sheltering effect of the Raso Cape. Closer to the Caparica coast, Hs for waves coming the NW is further reduced by refraction over the ebb delta, and can reach over $50 \%$.

\subsection{Exchanges between the Cachopo Sul and the adjacent beaches}

The seasonal evolution of the Tagus Estuary inlet was characterized based on simulations for a representative maritime winter (1990-1991, Figure 8) and summer (1989, Figure 11). These two periods were selected as those whose wave energy and direction were closest to the mean within a 71year period (Figure 6). The analysis focused on maps of residual sediment fluxes and erosion/deposition patterns.

The residual sediment transport during the maritime winter (Figure 8a) presents many similarities with the conceptual model of Oliveira (1973). In particular: residual sediment fluxes are directed seaward along the navigation channel; the transport over the Cachopo Sul is directed towards the estuary; and the transport over this bank is partially fed by sediments that come from the estuary following approximately the outer edge of the bank, and also by the littoral drift along the Caparica beaches. However, the numerical model also provides additional details. The littoral drift along the Caparica beaches is partially balanced by fluxes with the opposite direction further offshore. Elias and Hansen (2013) observed a similar behavior in simulations of sediment dynamics in the San Francisco Bay inlet. At the northern edge of the Caparica coast, there is a significant shoreward transport. Along the coast to the north of the inlet mouth, residual fluxes are also directed towards the inlet mouth, which is consistent with the conceptual model of Taborda and Andrade (2017). The accretion and erosion patterns predicted by the model (Figure $8 \mathrm{~b}$ ) are also consistent with the existing knowledge: the Cachopo Sul is growing northward and its bed forms are migrating to the north and to the east. 

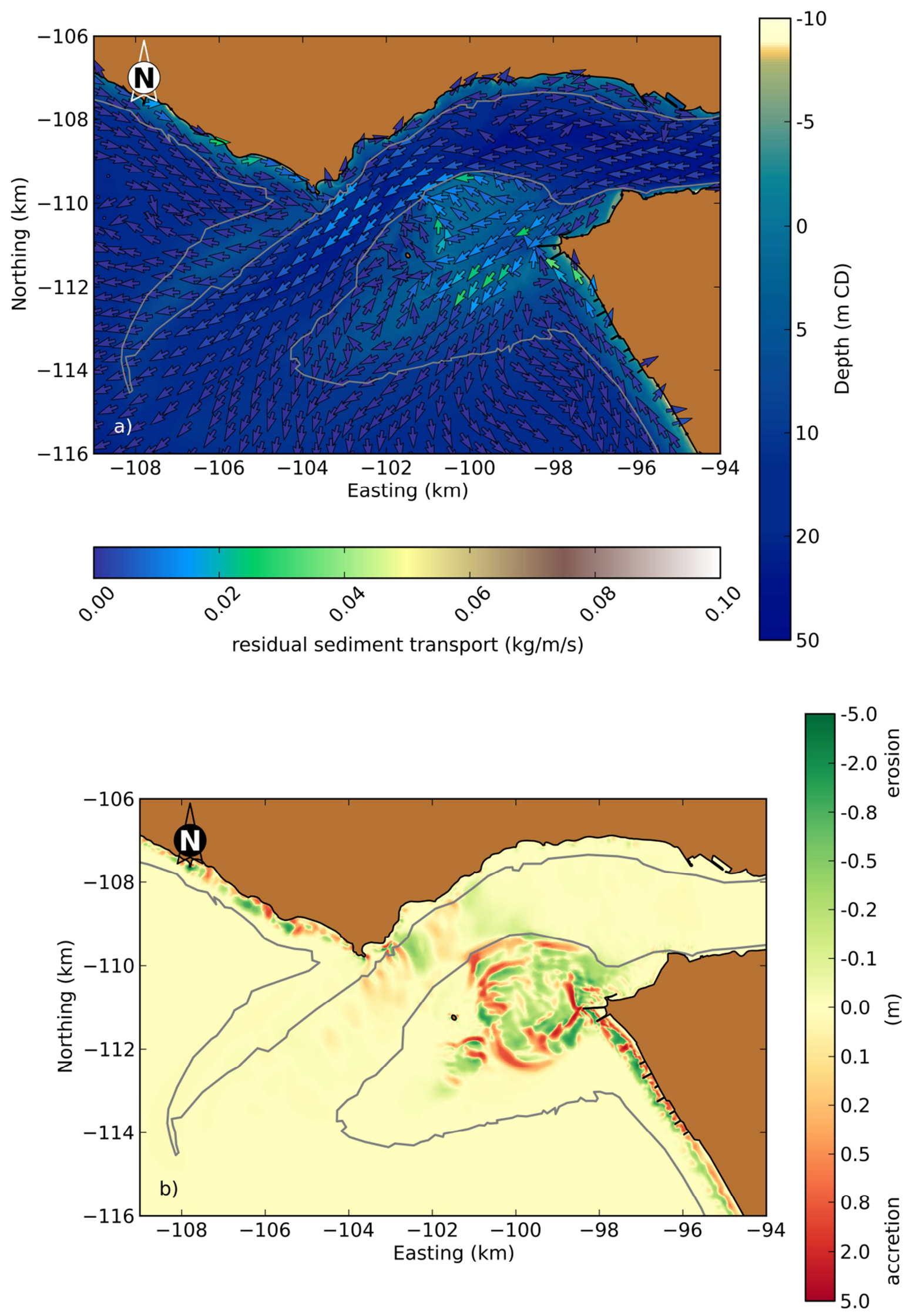

Figure 11. Morphodynamics of the Tagus Estuary inlet during a mean maritime summer (1989): a) residual sediment fluxes; b) erosion/deposition patterns. 
In the maritime summer, the magnitude of the residual sediment fluxes is about half as it is in the winter (Figure 11a). As a result, the morphological evolution is also smaller (Figure 11b). In terms of direction, the major difference occurs over the Cachopo Sul, where residual sediment fluxes are directed seaward. This direction should occur when waves do not exceed 1-2 $\mathrm{m}$ at the seaward edge of the ebb-delta and sediment transport is tidally-driven, as shown in the previous sub-section. This seasonal seaward transport of sand from the Cachopo Sul suggests that this shoal could be a sediment source for the Caparica beaches under some circumstances. However, residual fluxes from the Cachopo Sul are not directed towards the Caparica beaches but rather towards the southwest. Hence, we hypothesize that the sediments carried to the southwest by the ebb currents over the Cachopo Sul can later be mobilized by waves to feed the northern part of the Caparica beaches. This hypothesis is consistent with the analysis of Pinto (2013) who found that the speed at which the beaches along the Caparica coast recover after a storm decreases rapidly to the south. Also, since the tidally-driven sediment transport over the Cachopo Sul is not directed towards the Caparica beaches, these beaches should not respond immediately to low-energy periods. Instead, adequate wave conditions must occur for the sediments originating from the Cachopo Sul to be transported to the Caparica beaches.

The results of simulations S1-S8 suggest that the wave conditions that move sediments towards the beach are very specific. In particular, only simulation S5, with $4 \mathrm{~m}$ waves coming from the west, predicts sediment transport towards the Caparica beaches (Figure 10e). Smaller waves are unable to mobilize the sediments (Figure 10a-d), while longitudinal transport dominates for larger waves (Figure 10f). In addition, larger waves will trigger a strong undertow and erode the beach. Similarly, the beach is fed by sediments from the Cachopo Sul only when waves come from the west. Waves coming from the southwest generate a strong longshore drift to the northwest (Figure 10g) due to their strong obliquity; and waves coming from the northwest have a limited impact on the sediment dynamics (Figure 10h) because they are intercepted and diffracted by the Raso cape and refracted by the ebb delta.

Some simplifications of the model configuration used herein prevent a detailed analysis of the crossshore transport. In particular, the vertical structure of the flow cannot be adequately represented with a 2DH circulation model. Hence, in order to further verify the hypothesis that the sediments carried seaward by the ebb jet over the Cachopo Sul can later be transported by waves to the Caparica beaches, the power and the direction of the waves in front of these beaches were analyzed based on hindcast simulations. The wave model WaveWatch III was applied to the North Atlantic, with a nested grid in the Portuguese shelf (Fortunato et al., 2017b), and run from 1979 to 2018 forced by ERA-INTERIM winds. Results, output every 6 hours, show that the two periods during which a significant accretion of the Caparica beaches was observed (i.e., between July 2009 and May 2010, and between June 2013 and July 2014) were characterized by an energy above average (Table 5). Hence, it is not during low energy periods that the beaches are nourished with sediments coming from the Cachopo Sul. Similarly, the mean wave direction during these periods does not explain the observations, since the angle of wave propagation is lower than the mean during the first period and slightly higher during the second (Table 5).

The hypothesis that certain pairs of wave height and direction are particularly conducive to the growth of the northern Caparica beaches was evaluated using the same hindcast results, again outputted every 6 hours. Figure 12 highlights in yellow the outputs when Hs varies between 3 and $5 \mathrm{~m}$ and the wave direction varies between 250 and 290 degrees (i.e., waves from the west with a significant wave height of about $4 \mathrm{~m}$ ). The number of outputs per maritime winter with these conditions varies between 13 (in 1992/93) and 156 (in 2013/14), with an average of 60. The two periods during which an accretion of the Caparica beaches and an erosion of the Cachopo Sul were detected corresponded to the $1^{\text {st }}$ and $8^{\text {th }}$ maritime winters during which more occurrences are observed (2013/14 and 2009/10, as described in section 2.2). Hence, there are strong indications that Caparica beaches can be nourished by sediments from the Cachopo Sul under specific wave conditions (waves from the west with significant wave heights of about $4 \mathrm{~m}$ ). Note that no bathymetric data are available to verify the exchanges between the Cachopo Sul and the Caparica beaches during the other years. 

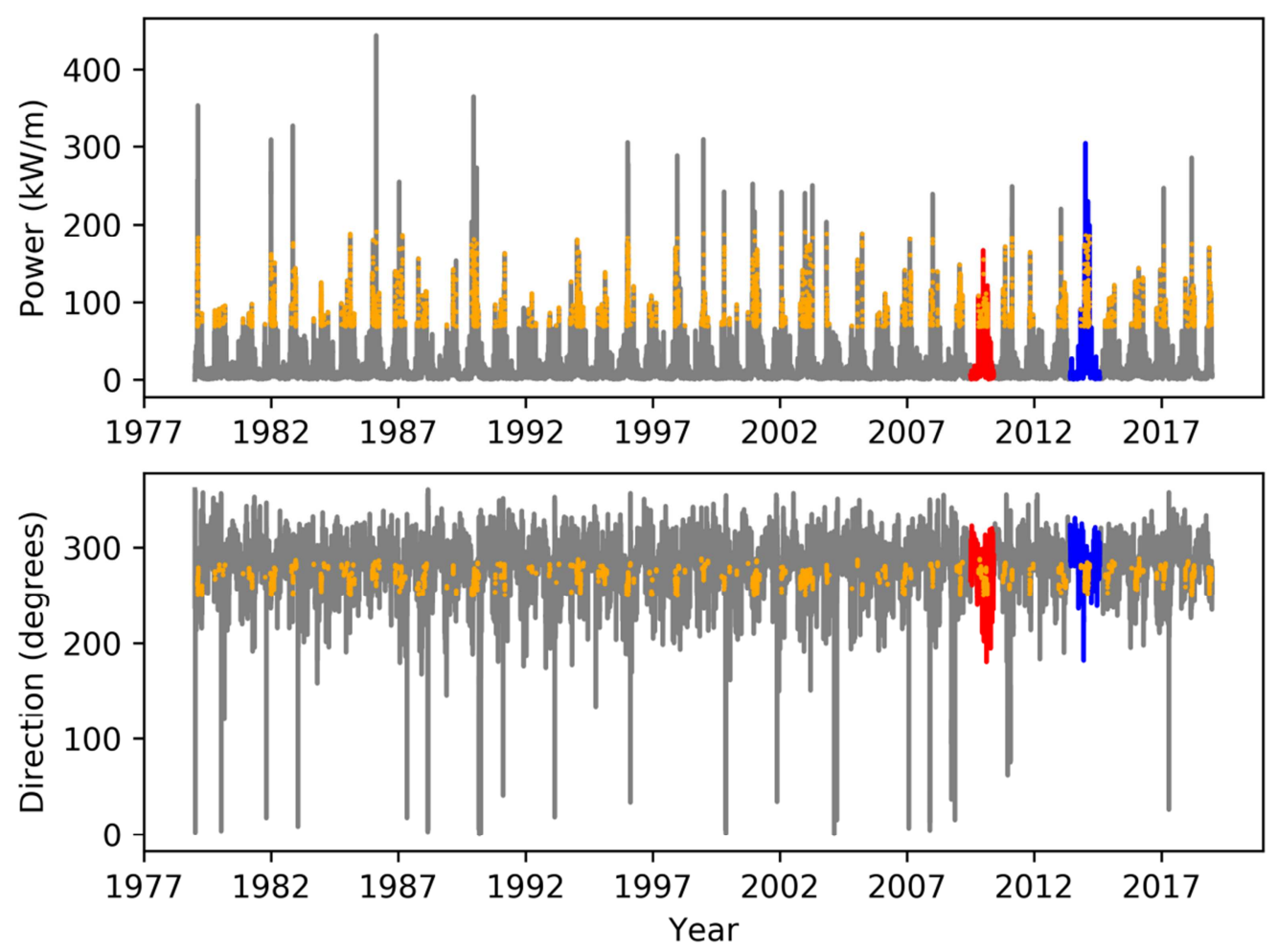

Figure 12. Wave power and direction in front of the Caparica beaches between 1979 and 2018 from model hindcasts. The red and blue lines indicate the periods during which the Caparica beaches accreted naturally. The orange dots indicate significant wave heights between 3 and 5 m, and wave directions between 250 and 290 degrees.

Table 5. Mean power and wave direction in front of the Caparica beaches

\begin{tabular}{l|ccc}
\hline & $1979-2018$ & July 2009 - May 2010 & June 2013 - July 2014 \\
\hline Wave power (kW/m) & 14.1 & 18.2 & 17.0 \\
Wave direction (degrees) & 275 & 265 & 276 \\
\hline
\end{tabular}

\subsection{Foreseeable evolution}

Contrary to other inlets, whose morphology exhibits a cyclical behavior (e.g., Nahon et al., 2019, Lenstra et al., 2019), the Tagus Estuary showed an apparent stability for over a century, followed by a persistent trend in the past seven decades. The persistent erosion of the Cachopo Sul raises concerns about the future evolution of this bank. These concerns are further intensified by sea level rise, which also contributes to the increase in water depth over this bank. This section aims at assessing the possible evolution of the bank by determining the feedback between the erosion of the bank and its sediment dynamics.

From a qualitative viewpoint, the feedback mechanisms are difficult to anticipate. On the one hand, the growth of the water depth over the sandbank reduces friction, thereby increasing the velocities and the sediment fluxes. Indeed, if the barotropic pressure gradient between the estuary and the sea is assumed to remain unchanged, the reduction of frictional effects over the sandbank increases the velocities over this bank by shifting part of the tidal prism from the navigation channel to the sandbank. Simultaneously, higher wave heights over the bank will enhance the wave stirring and thus the sediment fluxes. This suggests a positive feedback, where the erosion of the bank, together with sea level rise, promotes further erosion. On the other hand, the deepening of the bank reduces shear stress for a given velocity, thus reduces sediment fluxes. Also, the higher water depths will reduce the occurrence of events during which waves break over the sand bank and generate sediment transport towards the estuary. The balance between the different mechanisms is therefore difficult to anticipate, and model simulations can help identify the dominant process. 
The model was run again for the 1990/91 winter, for two alternative configurations. In the first (Figure 13), the bathymetry was modified by artificially eroding the bank by 0 to $0.5 \mathrm{~m}$. The erosion is zero for bed elevations above $-5 \mathrm{~m}$ (above Chart Datum, CD, which is close to the Lower Astronomic Tide) or below $10 \mathrm{~m}(\mathrm{CD}), 0.5 \mathrm{~m}$ for depths between 0 and $5 \mathrm{~m}(\mathrm{CD})$, and varies linearly in the intermediate intervals. In the second configuration, the bathymetry of the whole domain was lowered by $0.5 \mathrm{~m}$ (Figure 14), to mimic a similar rise in mean sea level.

Results highlight changes in the residual sediment transport patterns over the Cachopo Sul for both simulations (Figure 13, Figure 14). In particular, the northward sediment fluxes due to waves increase in the western and southern parts of the bank by up to a factor of two, and the southward sediment fluxes due to tides decrease in the eastern part. Simultaneously, the seaward sediment fluxes in the navigation channel decrease, reflecting the partial shift in tidal prism from the main channel to the Cachopo Sul. Simulations without considering the effect of wave asymmetry on sediment transport (not shown) suggest that this mechanism explains most of these changes. The changes are very similar for the sea level rise and for the erosion scenario. These results suggest that a higher depth in the Cachopo Sul magnifies the existing northward progradation of the Cachopo Sul, and favors the wavedriven over the tidally-driven transport.

These results have important implications. The dominance of the positive feedback suggests that the erosive trend will continue, so the Cachopo Sul does not appear to be moving towards a new equilibrium in the foreseeable future.

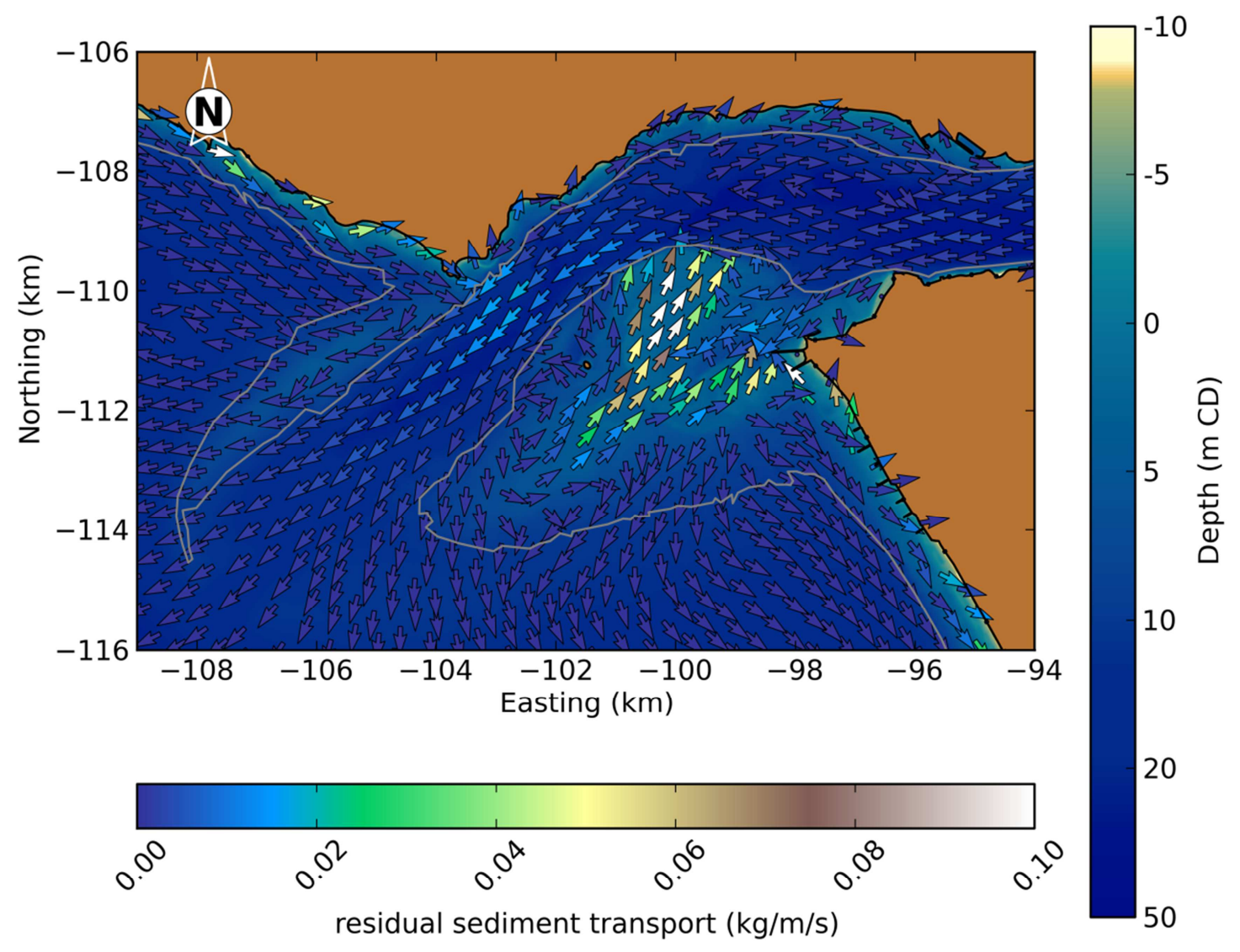

Figure 13. Effect of the erosion of the Cachopo Sul on the morphodynamics of the Tagus Estuary inlet during a mean maritime winter (1990/91): residual sediment fluxes. 


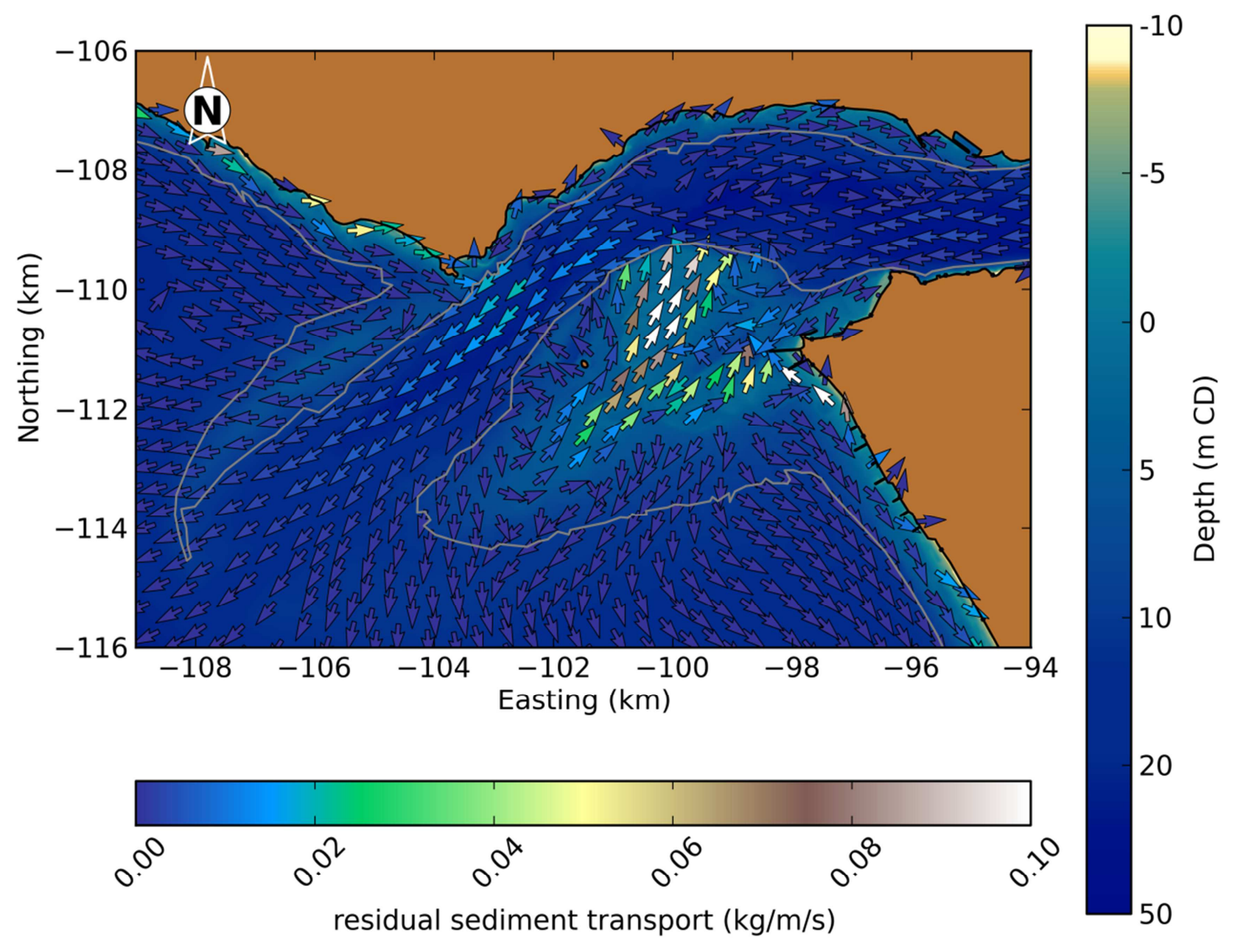

Figure 14. Effect of a $0.5 \mathrm{~m}$ rise in mean sea level on the morphodynamics of the Tagus Estuary inlet during a mean maritime winter (1990/91): residual sediment fluxes.

\section{Summary and conclusions}

This study contributed to the understanding of the sediment dynamics (fluxes and morphodynamics) of the inlet of one of the largest European estuaries through a review of past studies, the analysis of field data, and the implementation of a numerical model.

The analysis of the different forcings shows the dominant role of waves on the sediment dynamics and morphological evolution. The major evolution trends previously identified occur during storms, in particular those coming from the south-west. However, some relevant trends, like the southward rotation of the Cachopo Norte and the resulting accretion of the navigation channel, are due to waves coming from the west.

Based on seasonal morphodynamic simulations, we proposed a new conceptual model of the inlet's sediment dynamics that distinguishes the behavior during the maritime winter (Figure 8) and summer (Figure 11). This model is consistent with the existing knowledge based on field data and offers a detailed picture of the sediment dynamics. In the winter, the residual sediment transport is directed seaward in the navigation channel, towards the inlet mouth along the beaches adjacent to the inlet and towards the southwest over the north bank. These fluxes are directed towards the estuary over the Cachopo Sul, with the exception of a lateral channel (Golada) close to the margin. During the maritime summer, residual sediment fluxes are approximately half those occurring during winter. Tidally-driven transport becomes dominant relative to wave-driven transport, which leads to sediment fluxes directed towards the southwest over the Cachopo Sul.

The analysis suggests that the sediment deposits formed during the summer can be mobilized under specific wave conditions and transported to the northern stretch of the Caparica beaches. The transfer of sediments from the ebb delta to the adjacent beach has been identified in other large inlets as well 
(e.g., San Francisco Bay - Hansen et al., 2013). The particularity of the Tagus case is that this transfer seems to occur even though the yearly-mean residual transport is directed towards the inlet. Still, some limitations of the model configuration used herein recommend further analyzing this hypothesis with a 3D model that better represents the cross-shore transport.

Numerical experiments indicate the existence of a positive feedback between the erosion of the Cachopo Sul - or, similarly, sea level rise - and the sediment fluxes over this bank. This feedback suggests that the evolution of the bank observed during the last decades will continue in the foreseeable future.

\section{Acknowledgements}

Funding from the Agência Portuguesa do Ambiente, I.P., the Administração do Porto de Lisboa, S.A., and the Fondation de France supporting the project Segundo Torrão from the Nouveaux Commanditaires program is gratefully acknowledged. This work was also partially supported by the project INLEX, funded by the Fundação para a Ciência e a Tecnologia (FCT) and the Agence Nationale de la Recherche. This work was produced with the support of INCD funded by FCT and FEDER under the project 01/SAICT/2016 $\mathrm{n}^{\circ}$ 022153. Comments and suggestions from three anonymous reviewers of this manuscript are acknowledged.

\section{Data availability}

The most recent bathymetric data used herein are publicly available at https://cosmo.apambiente.pt/.

\section{References}

Araújo, I.B., J.M. Dias, D.T. Pugh 2008. Model simulations of tidal changes in a coastal lagoon, the Ria de Aveiro (Portugal), Continental Shelf Research, 28/8: 1010-1025.

Aubrey, D.G., P.E. Speer 1985. A study of non-linear tidal propagation in shallow inlet/estuarine systems Part I: Observations, Estuarine, Coastal and Shelf Science, 21(2), 185-205.

Baptista Lopes, 1956. Evolução hidrográfica da zona marítima adjacente ao Bugio e Costa da Caparica, Informação 341/56-R.O., Direcção dos Serviços Marítimos, Direcção-Geral dos Serviços Hidráulicos (in Portuguese; unpublished repport).

Battjes J.A. (1974). Computation of set-up, longshore currents, run-up, and overtopping due to windgenerated waves. Rep. 74-2, Comm. on Hydraul., Department of Civil Engineering, Delft University of Technology, Delft, Netherlands.

Barceló, J.P. 1970. Estudo experimental do funcionamento hidráulico de campos de esporões marítimos inclinados. Memória no 372 do Laboratório Nacional de Engenharia Civil, Lisboa (in Portuguese).

Barnard, P.L., L.H. Erikson, E.P.L. Elias, P. Dartnell 2013. Sediment transport patterns in the San Francisco Bay Coastal System from cross-validation of bedform asymmetry and modeled residual flux, Marine Geology, 345:72-95, DOI: 10.1016/j.margeo.2012.10.011

Bertin, X., A. Oliveira, A.B. Fortunato 2009a. Simulating morphodynamics with unstructured grids: description and validation of a modeling system for coastal applications, Ocean Modelling, 28/1-3: 75-87 
Bertin, X., Fortunato, A.B., Oliveira, A. 2009b. A modeling-based analysis of processes driving wave-dominated inlets. Continental Shelf Research, 29/5-6: 819-834.

Bertin, X., Prouteau, E., Letetrel, C. 2013. A significant increase in wave height in the North Atlantic Ocean over the 20th century, Global and Planetary Change, 106: 77-83, DOI: 10.1016/j.gloplacha.2013.03.009.

Bertin, X., D. Mendes, K. Martins, A.B. Fortunato, L. Lavaud 2019. The Closure of a Shallow Tidal Inlet Promoted by Infragravity Waves, Geophysical Research Letters, 46/12: 6804-6810, doi: 10.1029/2019GL083527

Billy, J., Chaumillon, E., Fenies, H., Poirier, C. 2012. Tidal and fluvial controls on the morphological evolution of a lobate estuarine tidal bar: The Plassac Tidal Bar in the Gironde Estuary (France), Geomorphology, 169: 86-97

Brown, C.A., Jackson, G.A. Brooks, D.A. 2000. Particle transport through a narrow tidal inlet due to tidal forcing and implications for larval transport, Journal of Geophysical Research - Oceans, 105(C10), 24141-24156

Bruneau, N., Fortunato, A.B., Dodet, G., Freire, P., Oliveira, A., Bertin, X., 2011. Future evolution of a tidal inlet due to changes in wave climate, sea level and lagoon morphology (Óbidos Lagoon, Portugal), Continental Shelf Research, 31/18: 1915-1930. doi:10.1016/j.csr.2011.09.001.

Cayocca. F. 2001. Long-term morphological modeling of a tidal inlet: the Arcachon Basin, France, Coastal Engineering, 42/2: 115-142

Dee, D.P., Uppala SM, Simmons AJ, Berrisford P, Poli P, Kobayashi S, Andrae U, Balmaseda MA, Balsamo G, Bauer P, Bechtold P, Beljaars ACM, van de Berg L, Bidlot J, Bormann N, Delsol C, Dragani R, Fuentes M, Geer AJ, Haimberger L, Healy SB, Hersbach H, Ho'lm EV, Isaksen L, Kallberg P, Kohler M, Matricardi M, McNally AP, Monge-Sanz BM, Morcrette JJ, Park B-K, Peubey C, de Rosnay P, Tavolato C, Thépaut J-N, Vitart F (2011). The ERAInterim reanalysis: configuration and performance of the data assimilation system. $Q J R$ Meteorol Soc 137:553-597. https://doi.org/10.1002/qi.828

DGSL, 1955 - Esboço topográfico mostrando a alteração da linha de costa imediatamente a sul da Barra do Tejo, entre 1939 e 1954. Direção de Serviços Marítimos (in Portuguese).

Dodet, G., X. Bertin, N. Bruneau, A.B. Fortunato, A. Nahon, A. Roland, 2013. Wave-current interactions in a wave-dominated tidal inlet, Journal of Geophysical Research: Oceans, DOI: $10.1002 / J G R C .20146$

Duong, T.M., Ranasinghe, R, Luijendijk, A., Walstra, D., Roelvink, D., 2017. Assessing climate change impacts on the stability of small tidal inlets: Part 1-Data poor environments, Marine Geology, 390: 331-346. DOI: 10.1016/j.margeo.2017.05.008

Elfrink, B., D.M. Hanes, B.G. Ruessink 2006. Parameterization and simulation of near bed orbital velocities under irregular waves in shallow water, Coastal Engineering, 53: 915-927.

Elias, E.P.L., Hansen, J.E., 2013. Understanding processes controlling sediment transports at the mouth of a highly energetic inlet system (San Francisco Bay, CA), Marine Geology, 345: 207220.

Fitzgerald, D.M. 1984. Interactions between the ebb-tidal delta and landward shoreline - Price Inlet, South-Carolina, Journal of Sedimentary Petrology, 54(4), 1303-1318

Fortunato, A.B., Oliveira, A., 2005. Influence of intertidal flats on tidal asymmetry, Journal of Coastal Research, 21(5), 1062-1067

Fortunato, A.B., A.M. Baptista, R.L. Luettich Jr. 1997. A three-dimensional model of tidal currents in the mouth of the Tagus estuary, Continental Shelf Research, 17/14: 1689-1714.

Fortunato, A.B., A. Oliveira, A.M. Baptista 1999. On the effect of tidal flats on the hydrodynamics of the Tagus Estuary, Oceanologica Acta, 22/1: 31-44. DOI: 10.1016/S0399-1784(99)80030-9 
Fortunato, A.B., Li, K., Bertin, X., Rodrigues, M., Miguez, B.M. 2016. Determination of extreme sea levels along the Iberian Atlantic coast, Ocean Engineering 111, 1: 471-482. doi: 10.1016/j.oceaneng.2015.11.031

Fortunato, A.B., Freire, P., Bertin, X., Rodrigues, M., Ferreira, J., Liberato, M.L. 2017a. A numerical study of the February 15, 1941 storm in the Tagus Estuary, Continental Shelf Research 144: 50-64. doi: 10.1016/j.csr.2017.06.023

Fortunato, A.B., A. Oliveira, J. Rogeiro, R. Tavares da Costa, J.L. Gomes, K. Li, G. Jesus, P. Freire, A. Rilo, A. Mendes, M. Rodrigues, A. Azevedo, 2017b. Operational forecast framework applied to extreme sea levels at regional and local scales, Journal of Operational Oceanography, 10/1: 1-15.

Franz, G., Delpey, M.T., Brito, D., Pinto, L., Leitão, P., Neves, R. 2017. Modelling of sediment transport and morphological evolution under the combined action of waves and currents, Ocean Science, 13/5: 673-690. DOI: 10.5194/os-13-673-2017

Garcia-Oliva, M. C. Marcos, G. Umgiesser, W. McKiver, M. Ghezzo, F. de Pascalis, A. Perez-Ruzafa 2019. Modelling the impact of dredging inlets on the salinity and temperature regimes in coastal lagoons, Ocean \& Coastal Management, 180: 104913, DOI: 10.1016/j.ocecoaman.2019.104913

Gong, W.P., Shen, J., Jia, J.J. 2009. Feedback between tidal hydrodynamics and morphological changes induced by natural process and human interventions in a wave-dominated tidal inlet: Xiaohai, Hainan, China. Acta Oceanologica Sinica, 28/3: 93-113.

Grant, W.D., Madsen, O.S. 1979. Combined wave and current interaction with a rough bottom, Journal of Geophysical Research, 84: 1797-1808, 10.1029/JC084iC04p01797

Guérin, T., X. Bertin, E. Chaumillon 2016a. Wave control on the rhythmic development of a wide estuary mouth sandbank: A process-based modelling study, Marine Geology, 380: 79-89.

Guérin, T., Bertin, X., Dodet, G. 2016b. A numerical scheme for coastal morphodynamic modelling on unstructured grids. Ocean Modelling, 104, 45-53.

Guerreiro, M., A.B. Fortunato, P. Freire, A. Rilo, R. Taborda, M.C. Freitas, C. Andrade, T. Silva, M. Rodrigues, X. Bertin, A. Azevedo 2015. Evolution of the hydrodynamics of the Tagus Estuary (Portugal) in the 21st century, Revista de Gestão Costeira Integrada, 15: 65-80. DOI: $10.5894 / \mathrm{rgci} 515$

Hansen, J.E., Elias, E., Barnard, P.L. (2013). Changes in surfzone morphodynamics driven by multidecadal contraction of a large ebb-delta, Marine Geology, 345: 221-234.

Hayes, M.O. 1979. Barrier Island morphology as a function of tidal and wave regime, Leatherman (Ed.), Barrier Island, Academic Press, New York, pp. 1-28

Hubbard, D. K., G.F. Oertel, D. Nummedal 1979. The role of waves and tidal currents in the development of tidal-inlet sedimentary structures and sand body geometry: examples from North Carolina, South Carolina, and Georgia, SEPM Journal of Sedimentary Research, 49, doi:10.1306/212F78B5-2B24-11D7-8648000102C1865D.

Hydronamic, 1982. Hydro-morphological study Tagus Estuary - Morphological model outer estuary.

Jarrett, J.T. 1976. Tidal prism-inlet area relationships. General Investigations of tidal inlets. 1-28. Academic Press, New York. Rep. No 3, Coastal Engineering. Research Center, Ft. Belvoir, VA, $32 \mathrm{pp}$.

Lenstra, K.J.H., S.R.P.M. Pluis, W. Ridderinkhof, G. Ruessink, M. van der Vegt (2019). Cyclic channel-shoal dynamics at the Ameland inlet: the impact on waves, tides, and sediment transport, Ocean Dynamics, 69: 409-425

Lesser, G.R., Roelvink, J.A., van Kester, J.A.T.M., Stelling, G.S. 2004. Development and validation of a three-dimensional morphological model. Coastal Engineering, 51: 883-915. 
Lira, C., R. Taborda 2014. Advances in applied remote sensing to coastal environments using free satellite imagery. Advances in Coastal and Marine Resources: Remote Sensing and Modeling [Coastal Research Library, Finkl, C.W., Makowski, C. (Eds.)], 9, 4: 77-102.

Lira, C.P., A.N. Silva, R. Taborda, C.F. Andrade 2016. Coastline evolution of Portuguese low-lying sandy coast in the last 50 years: an integrated approach, Earth System Science Data, 8/1: 265278.

Longuet-Higgins, M.S., Stewart, R.W. 1962. Radiation stress and mass transport in gravity waves, with application to 'surf beats', Journal of Fluid Mechanics, 13/4: 481-504, DOI: $10.1017 /$ S0022112062000877

Mendes, D.S.; Fortunato, A.B.; Pires-Silva, A.A. 2016. Assessment of three dredging plans for a wave-dominated inlet. Proceedings of the Institution of Civil Engineers - Maritime Engineering, 169/2: 64-75.

Moreira, S., Freitas, M.C., Andrade, C., Bertin, X. 2019. Processes controlling morphodynamics of artificially breached barriers, Estuarine Coastal and Shelf Science, 225: 106231, DOI: 10.1016/j.ecss.2019.05.013

Nahon, A., X. Bertin, A.B. Fortunato, A. Oliveira 2012. Process-based 2DH morphodynamic modeling of tidal inlets: a comparison with empirical classifications and theories, Marine Geology, 291-294: 1-11, DOI: 10.1016/J.MARGEO.2011.10.001

Nahon, A., D. Idier, N. Sénéchal, H. Féniès, C. Mallet, J. Mugica 2019. Imprints of wave climate and mean sea level variations in the dynamics of a coastal spit over the last 250 years: Cap Ferret, SW France. Earth Surface Processes and Landforms, 44/11: 2112-2125. DOI: 10.1002/esp. 4634

Nemus, 2010. Caracterização dos Sedimentos no Canal da Barral Sul do Porto de Lisboa, no Cachopo do Norte e nas Praias da Costa da Caparica. Volume I. Relatório Final. Dezembro 2010 (in Portuguese).

O'Brien, M.P. 1969. Equilibrium flow areas of inlets on sandy coasts, Journal of Waterways and Harbour Division, 95: 43-52

Oliveira, A., Fortunato, A.B., Rego, J.R.L. 2006. Effect of morphological changes on the hydrodynamics and flushing properties of the Óbidos lagoon (Portugal), Continental Shelf Research, 26/8: 917-942. DOI: 10.1016/j.csr.2006.02.011

Oliveira, A., Fortunato, A., Rodrigues, M., Azevedo, A. 2007. Integration of physical and water quality models. La Houille Blanche, 4: 40-46. DOI: 10.1051/lhb:2007076

Oliveira, E.M., A.B. Fortunato, J. Fortes, L.G. Silva, C. Vicente, M.C. Pereira 2000. Protecção do forte do Bugio contra a acção de ondas e correntes, Os Estuários de Portugal e os Planos de Bacia Hidrográfica, Associação EUROCOAST-Portugal, 181-201 (in Portuguese).

Oliveira, I.B.M 1973. Embocaduras lagunares. Contribuição para o estudo das suas condições de equilíbrio. Tese de doutoramento, Instituto Superior Técnico, Laboratório Nacional de Engenharia Civil, 434 pp (in Portuguese).

Oliveira, I.B.M., 1993. Port of Lisbon. Improvement of the Access Conditions through the Tagus Estuary Entrance, in Proceedings of the Coastal Engineering Conference, American Society of Civil Engineers, 3: 2745-2757.

Panda, U.S., Mohanty, P.K., Samal, R.N. 2013. Impact of tidal inlet and its geomorphological changes on lagoon environment: A numerical model study, Estuarine, Coastal and Shelf Science, 116, 29-40.

Pinto, C.A, Taborda, R., Andrade, C. 2007. Evolução recente da linha de costa no troço Cova do Vapor - S. João da Caparica. 5as Jornadas Portuguesas de Engenharia Costeira e Portuária, Lisboa. PIANC. AIPCN. Lisboa, 13 pp (in Portuguese). 
Pinto, C.A. 2013. Síntese preliminar e atualização dos resultados de monitorização das alimentações artificiais de praia na Costa da Caparica (2007-2013). Relatório Técnico n. ${ }^{\circ} 1 / 2013$. APA. 33p. (in Portuguese)

Pinto, C.A., Silveira, T., Taborda, R., 2014. Alimentação artificial das praias da Costa da Caparica. Síntese dos resultados da monitorização (2007 a 2014). Contributo para o Grupo de Trabalho do Litoral (Anexo VI). pp 213-237.

Pinto, C.A., Silveira, T., Taborda, R., 2015. Alimentação artificial das praias da Costa da Caparica: síntese dos resultados de monitorização (2007 a 2014): $3^{\text {a }}$ Conferência sobre morfodinâmica estuarina e costeira. Universidade do Algarve, 14-15 Maio 2015. Faro (in Portuguese).

Pinto, C.A., Silveira, T., Teixeira, S.B., 2020. Beach nourishment practice in mainland Portugal (1950-2017): overview and retrospective, Ocean \& Coastal Management, 192: 105211.

Reniers, A. J. H. M., Gallagher, E. L., MacMahan, J. H., Brown, J. A., Van Rooijen, A. A., Van Thiel de Vries, J. S. M., Van Prooijen, B. C. 2013. Observations and modeling of steep-beach grain-size variability. Journal of Geophysical Research: Oceans, 118(2), 577-591.

Renteria, F.F.G., Chirino, M.P.G., 2019. Effect of bathymetric changes on residence time in Buenaventura bay (Colombia), Dyna, 86/211:241-248, DOI: 10.15446/dyna.v86n211.79649

Rodrigues, M., Fortunato, A.B. 2017. Assessment of a three-dimensional baroclinic circulation model of the Tagus Estuary (Portugal), AIMS Environmental Science 4/6: 763-787. DOI: $\underline{10.3934 / \text { environsci.2017.6.763 }}$

Rodrigues, M., A.B. Fortunato, P. Freire, 2019. Saltwater intrusion in the upper Tagus Estuary during droughts, Geosciences, 9/9: 400, DOI: 10.3390/geosciences9090400

Roland, A., Zhang, Y. J., Wang, H. V., Meng, Y., Teng, Y.-C., Maderich, V., Brovchenko, I., DutourSikiric, M., Zanke, U. 2012. A fully coupled 3D wave-current interaction model on unstructured grids, Journal of Geophysical Research, 117(C11).

Santos, F.D., Lopes, A. M., Moniz, G., Ramos, L., Taborda, R. 2017. Grupo de Trabalho do Litoral: Gestão da Zona Costeira - O Desafio da Mudança. Filipe Duarte Santos, Gil Penha-Lopes e António Mota Lopes (Eds). Lisboa (ISBN: 978-989-99962-1-2) (in Portuguese).

Silva, J.F. 2013. Novo Terminal de Contentores em Lisboa, Revista de Marinha, 973 (in Portuguese).

Silva, A.N., Taborda, R., Bertin, X., Dodet, G. 2012. Seasonal to Decadal Variability of Longshore Sand Transport at the Northwest Coast of Portugal, Journal of Waterway Port Coastal and Ocean Engineering - ASCE, 138/6: 464-472, DOI: 10.1061/(ASCE)WW.1943-5460.0000152

Silva, S.F., Martinho, M., Capitão, R., Reis, T., Fortes, C.J., Ferreira, J.C. 2017. An index-based method for coastal-flood risk assessment in low-lying areas (Costa de Caparica, Portugal), Ocean \& Coastal Management, 144: 90-104.

Taborda, R., C. Andrade 2017. Morfodinâmica do Estuário Exterior do Tejo e Intervenção na Região da Caparica - v1, Anexo I de F.D. Santos, A.M. Lopes, G. Moniz, L. Ramos, R. Taborda (2017). Grupo de Trabalho do Litoral: Gestão da Zona Costeira: O desafio da mudança. F.D. Santos, G. Penha-Lopes e A.M. Lopes (Eds). Lisboa (ISBN: 978-989-99962-1-2) (in Portuguese).

Tran, T.T., J. M.J.F. Stive, D.J.T Walstra 2012. Cross-sectional stability of tidal inlets: A comparison between numerical and empirical approaches, Coastal Engineering, 60: 21-29, DOI: 10.1016/j.coastaleng.2011.08.005

van Rijn, L., D. Walstra, M.V. Ormondt 2004. Description of TRANSPOR2004 and implementation in DELFT3D-ONLINE: final report. Technical Report. Deltares (WL).

Velasquez-Montoya, L., M.F. Overton, E.J. Sciaudone 2020. Natural and anthropogenic-induced changes in a tidal inlet: Morphological evolution of Oregon Inlet, Geomorphology, 350/1: 106871 
Veloso Gomes, F., F. Taveira Pinto, J.P. Barbosa, J. Costa, A. Rodrigues 2006. Estudo das intervenções na Costa da Caparica. las Jornadas de Hidraúlica, Recursos Hídricos e Ambiente, FEUP, 27-35 (in Portuguese).

Veloso Gomes, F., J. Costa, A. Rodrigues, F. Taveira Pinto, J.P. Barbosa, L. Neves 2009. Costa da Caparica artificial sand nourishment and coastal dynamics. Journal of Coastal Research, Special Issue 56: 678-682.

Warner, J.C., C.R. Sherwood, R.P. Signell, C.K. Harris, H.G. Arango 2008. Development of a threedimensional, regional, coupled wave, current, and sediment-transport model. Computers and Geosciences, 34: 1284-1306.

Wentworth, C. K., 1922. A Scale of Grade and Class Terms for Clastic Sediments. Journal of Geology, 30: 377-392.

$\mathrm{Wu}, \mathrm{W} ., \mathrm{Q}$. Lin 2014. Nonuniform sediment transport under non-breaking waves and currents. Coastal Engineering, 90: 1-11.

Ye, F., Y.J. Zhang, H.C. Yu, W. Sun, S. Moghimi, E. Myers, K. Nunez, R. Zhang, H.V. Wang, A. Roland, K. Martins, X. Bertin, J. Dug, Z. Liu (2020). Simulating storm surge and compound flooding events with a creek-to-ocean model: importance of baroclinic effects. Ocean Modeling, 145: 101526.

Zhang, Y., A.M. Baptista 2008. SELFE: A semi-implicit Eulerian-Lagrangian finite-element model for cross-scale ocean circulation, Ocean Modelling, 21(3-4), 71-96.

Zhang, Y.J., Ye, F., Stanev, E.V., Grashorn, S., 2016. Seamless cross-scale modeling with schism. Ocean Modelling, 102, 64-81.

\section{Appendix: Determination of the sediment grain size}

\section{Beaches between São João and Trafaria}

Surface sediment samples were collected along cross-shore profiles at the São João de Caparica, Cova do Vapor, POL NATO, $2^{\circ}$ Torrão and Trafaria beaches (Figure 1) on February and June 2018. The silt and clay content (diameters under $63 \mu \mathrm{m}$ ) of each sample was obtained in laboratory through wet sieving. Sand grain size analysis was performed by dry sieving, using sieves from $4 \mathrm{~mm}(-2 \mathrm{phi})$ to $63 \mu \mathrm{m}(+4 \mathrm{phi})$, at $0.5 \mathrm{phi}$ intervals, where phi is the negative logarithm to the base 2 of the particle diameter in millimeters. Statistical parameters of the grain size distribution were obtained with EasySieve software $\odot$ Retsch. The samples were characterized based on the median diameter $\left(\mathrm{D}_{50}\right)$ and the spreading, defined as $\sigma=\left(\mathrm{D}_{84} / \mathrm{D}_{16}\right)^{0.5}$ where $\mathrm{D}_{16}$ and $\mathrm{D}_{84}$ are the $16^{\text {th }}$ and $84^{\text {th }}$ percentiles. The spreading quantifies the extent to which particles sizes are clustered around the central value; values closer to 1 corresponds to a very well sorted distribution. The sediment classification follows the Wentworth (1922) grain size classification (Wentworth, 1922).

Beach sediments are mainly composed of quartz sands with a median diameter ranging from 0.19 to $0.43 \mathrm{~mm}$ and an average value of $0.27 \mathrm{~mm}$ (Figure A. 1). The spreading varies between 1.22 and 1.60. S. João and Trafaria beaches present the finer and better sorted sediments, with $\mathrm{D}_{50}$ from 0.19 to 0.24 $\mathrm{mm}$ and mean spreading values of 1.28 and 1.33 , respectively. Cova do Vapor and $2^{\circ}$ Torrão beaches are composed of fine to medium sands with, respectively, $\mathrm{D}_{50}$ from 0.22 to $0.32 \mathrm{~mm}$ and $\mathrm{D}_{50}$ from 0.21 to $0.42 \mathrm{~mm}$. The mean spreading values of 1.34 and 1.41 in those beaches indicate, particularly in the $2^{\mathrm{a}}$ Torrão beach, the presence of less sorted sediments. The POL NATO beach presents the coarser and most poorly sorted sediments, with $\mathrm{D}_{50}$ between 0.35 and $0.43 \mathrm{~mm}$, and a mean spreading of 1.53 .

Previous studies that focused on some of these beaches (e.g. Freire, 2003) show that at least in the last two decades there has been no significant changes in the mean beach sediment characteristics. 


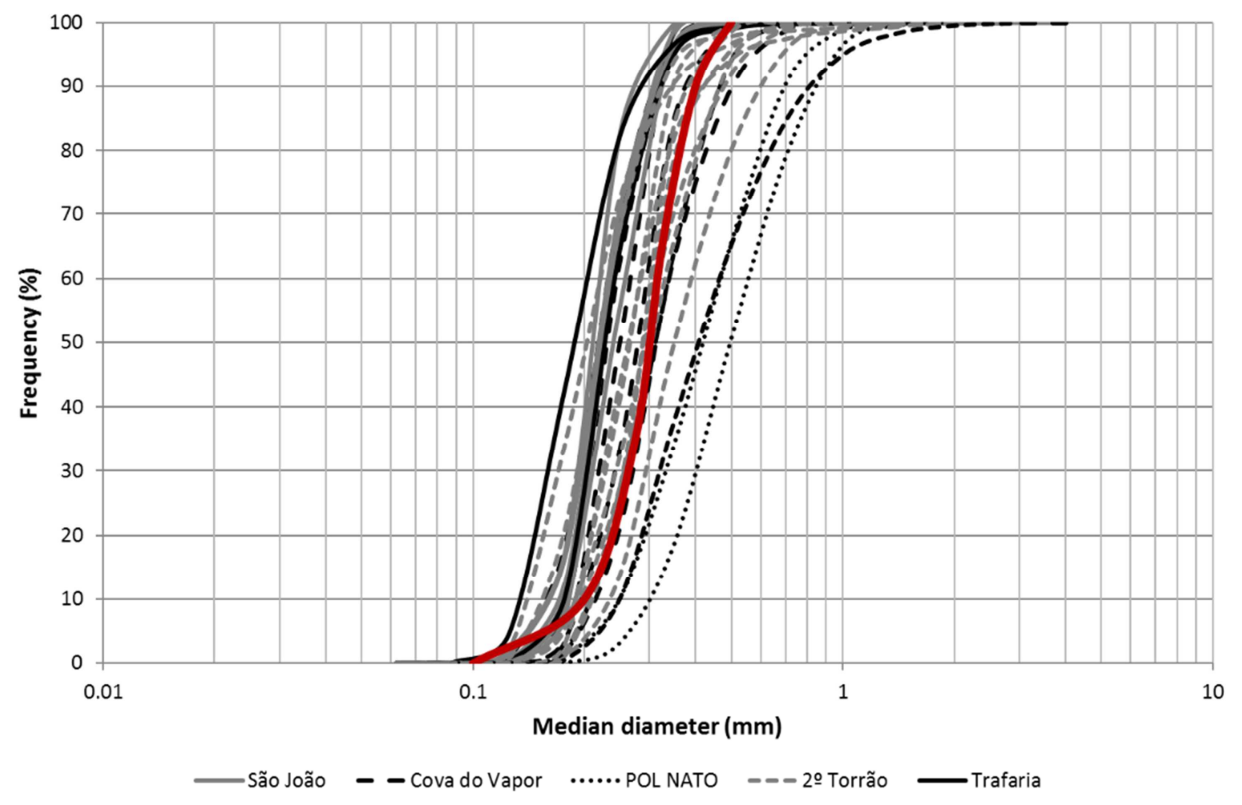

Figure A. 1. Grain size distribution of beach sediments and initial distribution used in the model (in red). Beaches are located in Figure 1.

\section{Bottom sediments in the estuary mouth}

The grain size distribution of the superficial bottom sediments in the estuary mouth is discussed based on the literature. Results from the two studies considered (Hydronamic, 1982; NEMUS, 2010) are summarized in Figure A. 2.

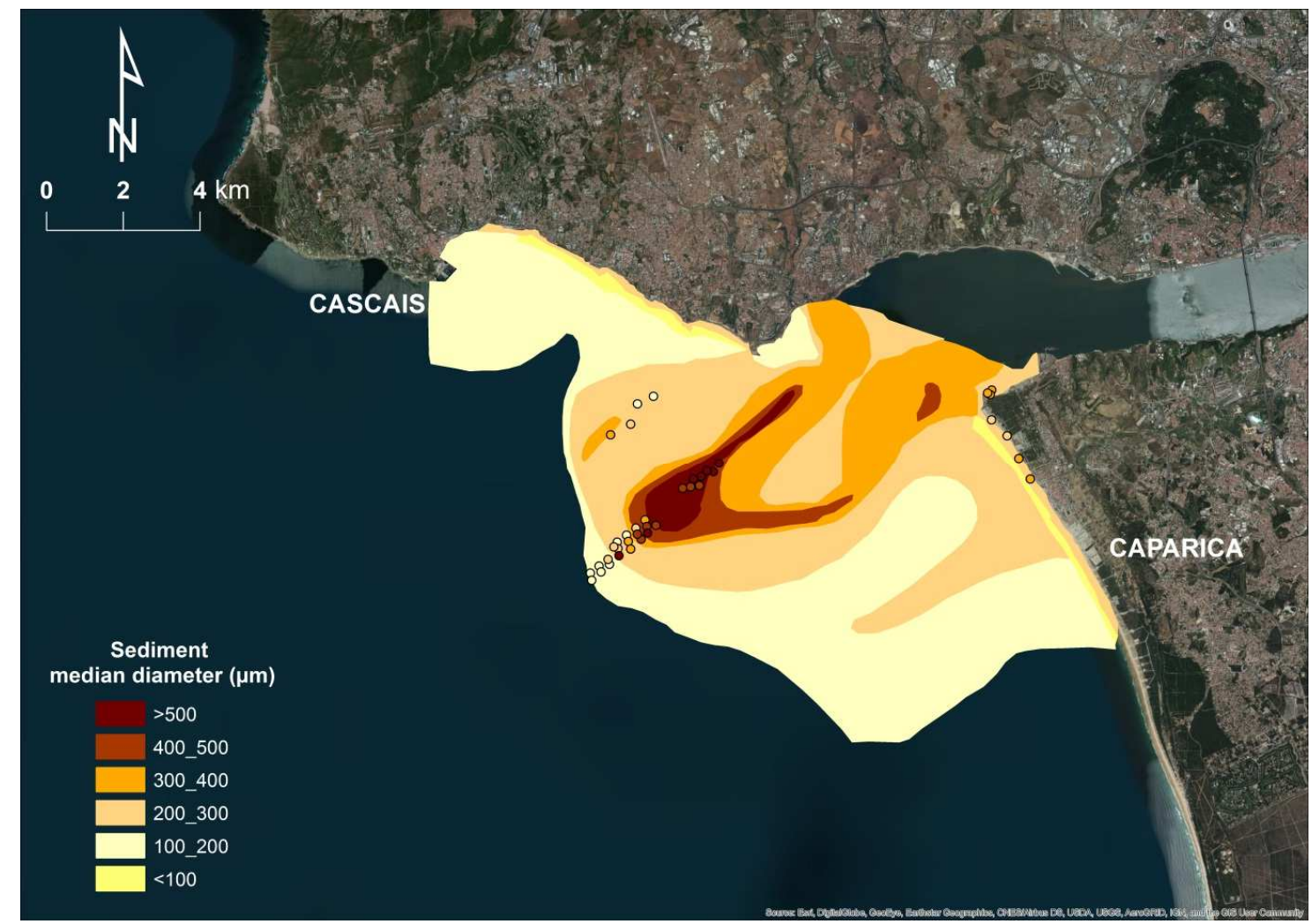

Figure A. 2. Grain size distribution of bottom sediments in the Tagus Estuary mouth based on Hydronamic (1982) and NEMUS (2010) results. 
Medium sands are mainly found in the Cachopo Sul and the Golada channel and the fine sands in the deepest zones along the Costa da Caparica coastal stretch and in the Cachopo Norte. In the latter the sand fraction represents about $89 \%$ of the total sediment and the silt and clay content (diameters under $0.063 \mathrm{~mm}$ ) is less than $11 \%$. The sand median diameter varies between 0.16 and $0.30 \mathrm{~mm}$, with a mean value of $0.2 \mathrm{~mm}$ (fine sand).

In the navigation channel (Barra Sul channel) sediments are coarser. The sand fraction accounts for more than $65 \%$ of the total sediment and the gravel $\left(\mathrm{D}_{50}>2.0 \mathrm{~mm}\right)$ can reach $29 \%$. The silt and clay content does not exceed $16 \%$. The sand median diameter varies between 0.15 and $0.70 \mathrm{~mm}$ with a mean value of $0.40 \mathrm{~mm}$ (corresponding to medium sands). 